\title{
ご挨 拶
}

第17回日本内分泌学会中国支部学術集会

会長 横田 敏彦

公益財団法人 大原記念倉敷中央医療機構 倉敷中央病院

内分泌代謝・リウマチ内科 主任部長

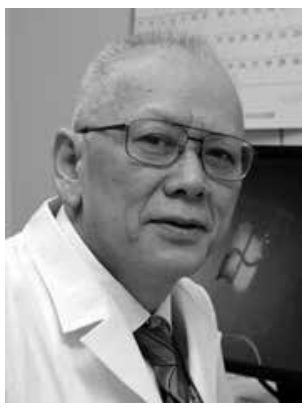

この度 第 17 回日本内分泌学会中国支部学術集会を 2016 年 8 月 27 日 (土)に開催させていただくことになり ました。開催のご挨拶を申し上げます。

内分泌臨床の醍醐味は、様々な分野から診断と治療を考えてゆくプロセスにあり、適切な診療は患者さん の予後に直結します。高齢化、少子化が進む今後の日本では、ますます重要になる領域と考えています。

21 世紀とともに始まった日本内分泌学会中国支部学術集会も、岡山県では通算4回目となります。今回は 初めて倉敷市内で開催し、思い切って会場も病院内としました。病院内開催のメリットを最大限に活かした 多様な運用を準備しました。

倉敷中央病院は、倉敷駅から徒歩 15分、倉敷美観地区からも徒歩 15分の場所です。お車で参加される方は、 山陽道倉敷インターから 10 分で、院内の駐車場 (無料)をご利用いただけます。また、倉敷駅から病院まで のシャトルバス 2 便を用意しました。1便は、正午 $(12: 00)$ から開催される支部連絡会議、ランチョンセミナー に合わせて11:35発、もう1便は、13:00 開会後の一般演題、JES We Can企画に合わせて 12:35発です。

皆様には多数の演題登録をいただき有り難うございました。特に各施設のコメディカルスタッフの方々か ら生理検査・超音波検査・細胞診検査など多岐にわたる6演題を登録していただきましたので、今回は疾患 領域別に院内 2 会場で一般演題 24 演題を編成しました。

また、中国支部連絡会議と同時開催となりますが、若手医師・コメディカルスタッフの方々を対象とした ランチョンセミナーを企画しました。隈病院臨床検査科 太田寿先生に甲状腺・副甲状腺超音波検査につい てのご講演をお願いしています。

今回の JES We Can企画 (13:10～14:10) は、甲状腺超音波\&穿刺吸引細胞診ハンズオンセミナーです。 まずは超音波装置の探触子を自らの手で動かしてみてはいかがでしょうか。

特別講演 $(16: 40 \sim 17: 40)$ は、甲状腺疾患と妊娠について精力的に臨床研究を発表されている国立成育医 療研究センター 荒田尚子先生にお願いしました。妊娠と甲状腺ホルモン、抗甲状腺薬と胎児異常との関連 など、最新の知見に基づいた明日からの臨床に役立つご講演を抒話しいただけるものと思います。

懇親会 $(17: 50 １ 8: 50)$ は、特別講演終了後に院内会場で予定していますので、是非ご参加ください。倉 敷駅までの帰りのシャトルバス便もご利用いただけます。

真夏の太陽が矓しい時候の開催で申し訳ありませんが、時間に余裕のある方は美観地区の観光もいかがで しょう。美観地区内には、近現代美術中心のコレクションをもつ大原美術館があります。

皆様には日々の臨床・研究成果のご発表をいただけますよう、宜しくお願い申し上げます。あわせて、次 世代の内分泌診療を担うスタッフ・研修医·学生を含め、より多くの皆様のご参加を心よりお待ちしています。 最後に、本学会開催にご協力・ご支援をいただきました多くの方々、協賛企業の皆さまに深く感謝申し上げ ます。 


\section{第17回日本内分泌学会中国支部学術集会}

会 長: 横田 敏彦

公益財団法人 大原記念倉敷中央医療機構 倉敷中央病院

内分泌代謝・リウマチ内科 主任部長

会 期：平成 28 年 8 月 27 日（土） 12:00 17:45

会 場：倉敷中央病院内

干 710-8602 岡山県倉敷市美和1-1-1

TEL : 086-422-0210

学術集会：12:00 17:45 外来棟 3 階「大原記念ホール」「第1会議室」

中国支部連絡会議： 12:00 12:50 3棟 3 階「会議室 $4 \cdot 5 」$

ランチョンセミナー：12:00１2:50 外来楝３階「大原記念ホール」

JES We Can企画：13:10 14:10 外来棟 3 階「第1会議室」

支部総会：15:55 16:05 外来棟 3 階「大原記念ホール」

特別講演：1 16:40 17:40 外来棟 3 階「大原記念ホール」

懇親会： $\quad 17: 50 〜 18: 50$ 温室地下 温室のレストラン 


\section{参加者へのご案内}

\section{1. 参加受付}

日時：8月 27 日（土） $11: 30 \sim 17: 00$

場所：総合受付（外来棟 3 階 ロビー）

\section{2. 参加費、抄録集販売など (現金受付のみ)}

医師 - 一般

コメディカル

学生・初期研修医

懇親会

プログラム・抄録集 1,000 円

・会場内では必ず参加証(兼領収書)に所属・氏名を記入のうえ、携帯してください。

・参加証 (兼領収書)の再発行はできませんので、大切に保管してください。

・学会員にはプログラム・抄録集を事前に扮送りいたしますので、忘れずご持参ください。

\section{3. 単位取得}

本学術集会参加により、日本内分泌学会認定内分泌代謝専門医更新に必要な 60 単位のうち、5 単位が修得可能です。

\section{4. ランチョンセミナー}

整理券の配布はございません。セミナー入場時にお弁当をお受け取りください。

\section{5. クローク}

\section{外来棟 3 階 第 3 会議室}

受付時間 11:30 18:00

\section{6. 会期中の問い合わせ先}

運営本部 (外来棟 3 階 第 2 会議室)

TEL : 086-422-0210 (内線 5028)

\section{7. その他}

・会場内では、携帯電話をマナーモードに設定してください。

・会場内は全館禁煙です。

・会長の許可の無い掲示・展示・印刷物の配布・録音・写真撮影・ビデオ撮影は固くお断りい たします。 


\section{座長・発表者へのご案内}

\section{1. 進行情報}

一般演題 発表 7 分、質疑 3 分

・円滑な進行のため、時間厳守でお願いします。

\section{2. 座長の皆さまへ}

・限られた時間内にて発表が円滑に進行するようご配慮ください。

・担当セッション開始予定時刻の 10 分前までに、会場内前方の「次座長席」にご着席ください。

\section{3. 発表者の皆さまへ}

\section{I . 利益相反の開示}

会員、非会員の別を問わず、筆頭発表者は該当するCOI状態について、発表スライドの最初（ま たは演題・発表者などを紹介するスライドの次）に情報開示をお願いします。

所定の様式は日本内分泌学会 HP (https://square.umin.ac.jp/endocrine/hottopics/coi-index.html) よりダウンロードできます。

\section{II. 試写・発表方法}

1）すべて PC 発表 (PowerPoint)のみといたします。

2）発表データは、PowerPoint 2003～2013のバージョンで作成してください。 ※ PowerPoint 2016には対応しておりません。

3）PowerPointの「発表者ツール」は使用できません。発表用原稿が必要な方は各自ご準備くだ さい。

4）学術集会当日に発表データの受付を行います。第1会場でご発表の方は、セッションの開始 30 分前までに「第1会場前PC受付」にて、第2会場でご発表の方 (一般演題に限る) は、14:10 〜 14:40に「第2会場内の演台上PC」にて、発表データの受付ならびに試写をお済ませください。 ※この時間以外の受付はできませんのでご注意ください。

5）スライド送りの操作は、データ持ち込み・PC 持ち込みのいずれの場合も、演台上のマウスま たはキーボードにてご自身で操作してください。

6）発表の 10 分前までに、次演者席にご着席ください。

\section{<データ発表の場合 >}

1）作成に使用された以外のPCでも必ず動作確認を行っていただき、USBフラッシュメモリー でご持参ください。

2）フォントは文字化け、レイアウト崩れを防ぐため下記フォントを推奨いたします。 MS ゴシック，MSPゴシック， MS 明朝，MSP明朝 Arial, Century, Century Gothic, Times New Roman

3）発表データは学術集会終了後、事務局で責任を持って消去いたします。 


\section{$<P C$ 本体持込みによる発表の場合 $>$}

1）Macintoshで作成したものと動画を含む場合は、必ずご自身のPC本体を抒持込みください。

2）会場で用意するPCケーブルコネクタの形状は、D-SUB mini 15pin (図参照)です。この出力 端子を持つ PCをご用意いただくか、この形状に変換するコネクタを必要とする場合には必 ずご持参ください。デジタル出力 (HDMI)の出力端子しか無いPCはHDMI $\rightarrow$ D-SUB の変換 アダプターも必要です。電源ケーブルもお忘れなく持ちください。

3）再起動をすることがありますので、パスワード入力は“不要”に設定してください。

4）スクリーンセーバーならびに省電力設定は事前に解除しておいてください。

5）動画デー夕使用の場合は、Windows Media Playerで再生可能であるものに限定いたします。

6）音声はご利用いただけませんので、ご了承ください。

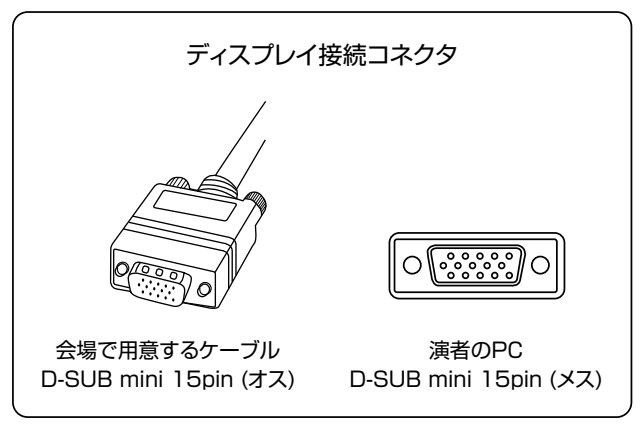

（図）

\section{主催：日本内分泌学会中国支部}

支部長 : 島根大学医学部 内科学講座内科学第一 杉本 利嗣

副支部長：鳥取大学医学部 周産期 - 小览医学 神崎晋

事務局 : 島根大学医学部 内科学講座内科学第一 杉本 利嗣 于 693-8501島根県出雲市塩治町 89-1

\section{連絡先：第17回日本内分泌学会中国支部学術集会 事務局}

公益財団法人 大原記念倉敷中央医療機構 倉敷中央病院 内分泌代謝・リウマチ内科 † 710-8602 岡山県倉敷市美和 1-1-1

TEL : 086-422-0210 FAX : 086-421-3424 


\section{交通のご案内}

JR倉敷駅から 徒歩 約15分

倉敷駅南口を出たら、倉敷センター街を通り抜け10分ほよ゙歩きます。

倉敷郵便局を左に見ながら信号を渡り、次の交差点を越えると、左手に当院への入口があります。

日クシー 約5分

電車でＪR岡山駅からJR倉敷駅まで

ロ山陽本線または伯備線 約17分、快速サンライナー 約13分

シャトルバスで ロ倉敷駅一会場間 約5分

発車時刻【行き】[倉敷駅発] 11:35/12:35【帰り】[会場発] 18:50

路線バスでロJR倉敷駅より

下電バス「中庄駅行」・肾島駅行 (天城線)」・「茶屋町駅行」で約10分 「中央病院前」下車

お車で

口倉敷IC (山陽自動車道) から約10分

、倉敷 I.C.方面

大島交差点

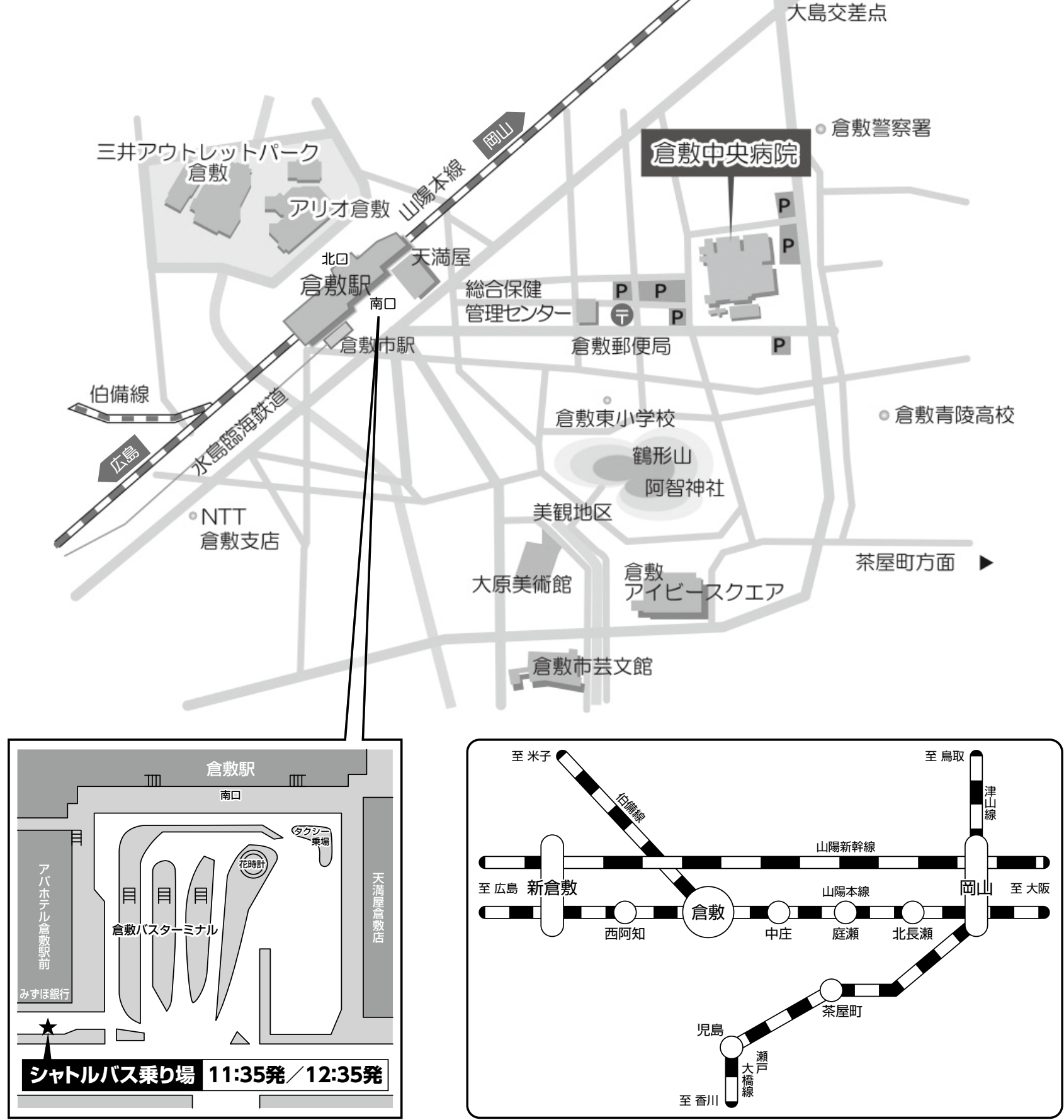


学術集会参加者は、当院の駐車場 (地図内 $($ 表示) を 無料でご利用いただけます。

駐車券を総合受付にご提出いただきましたら、

無料の駐車サービス券と交換いたします。

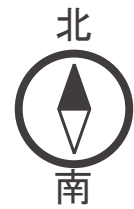

岡山方面

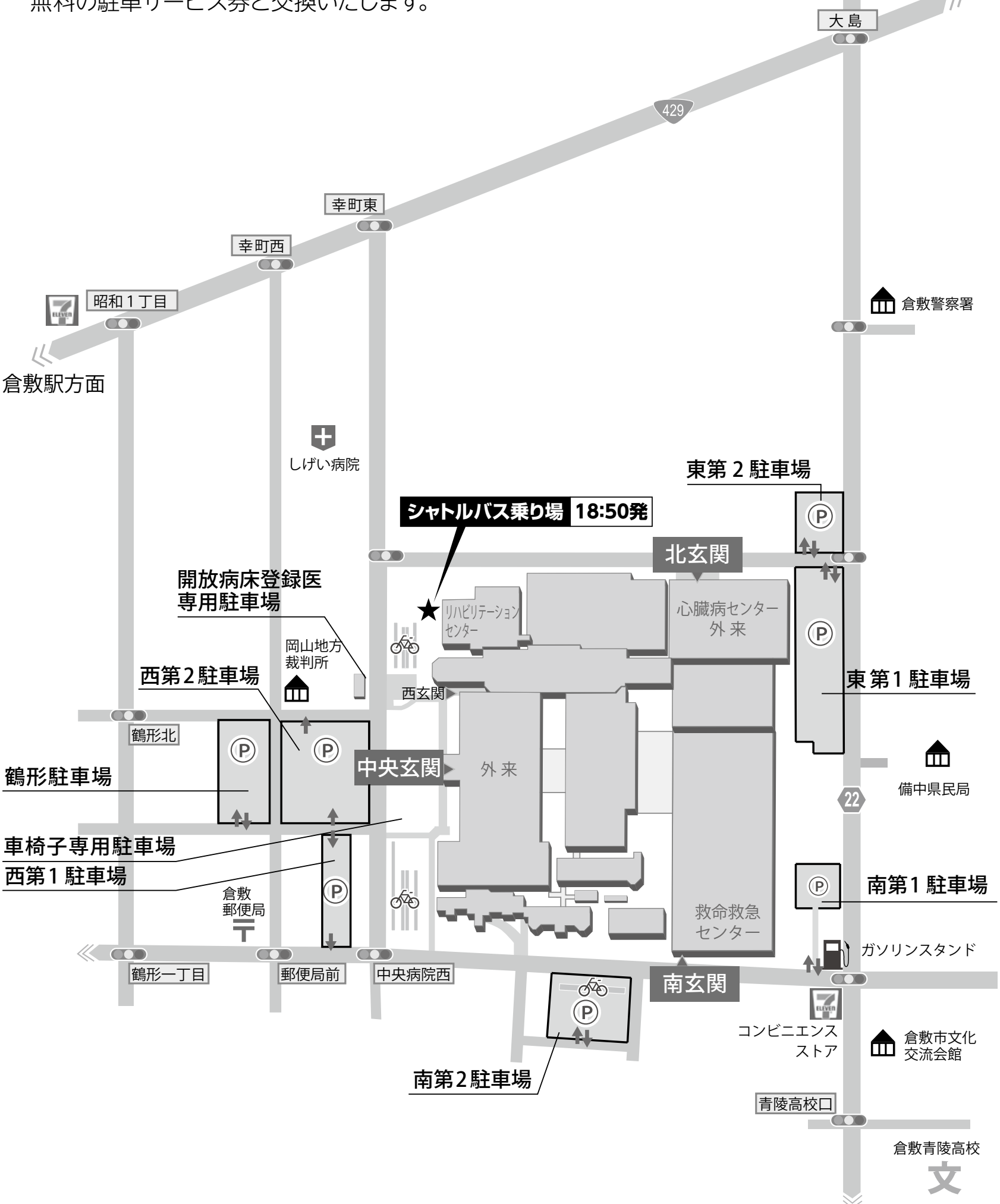

倉敷市民会館方面 


\section{会場案内図}

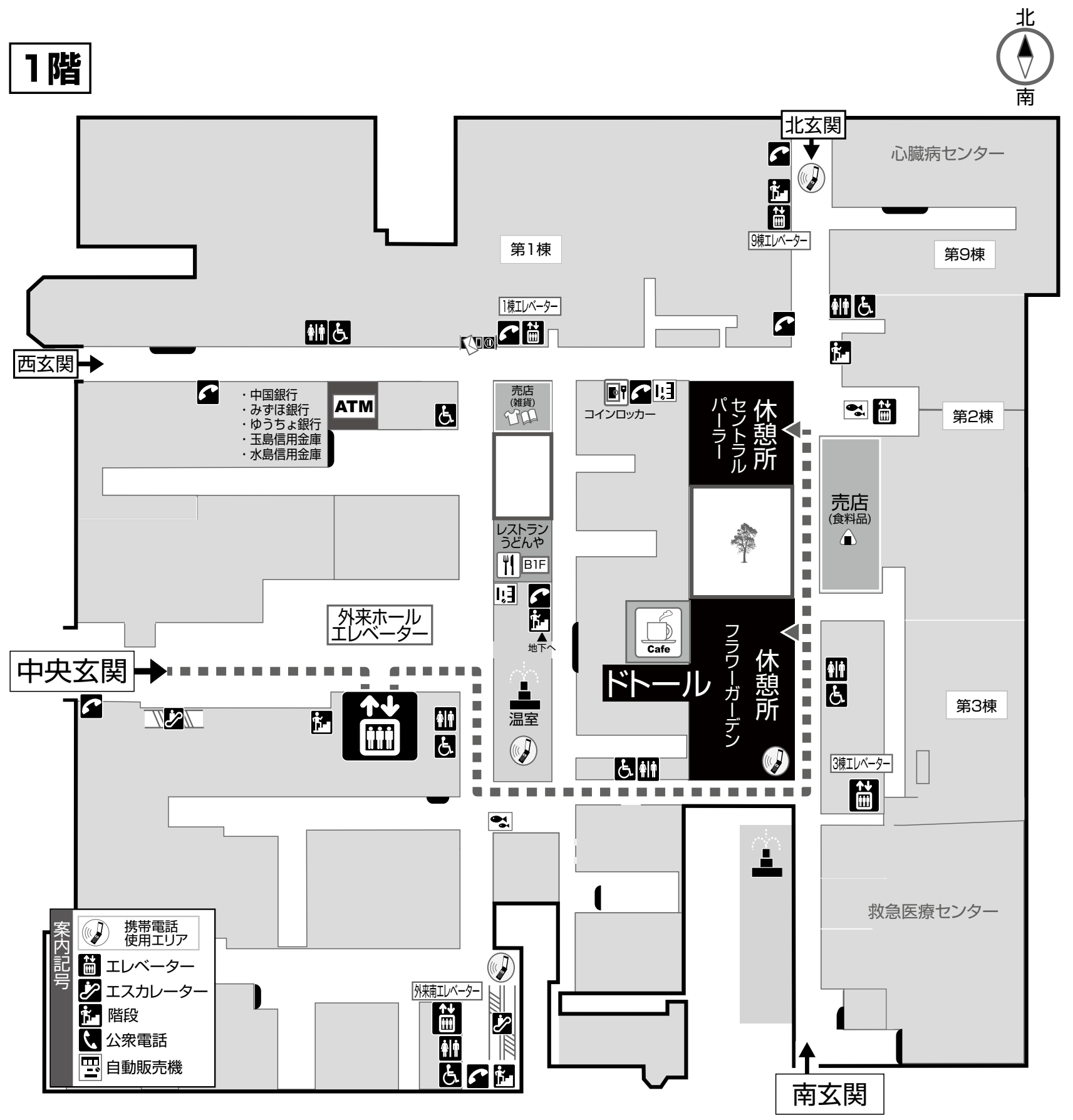

※支部連絡会議へご出席の方は、南玄関をご利用ください。

\section{第1会場・第2会場のて案内}

中央玄関からお入りいただき、外来ホールエレベーターで3階へお進みください。

\section{休熄所の案内}

1 階

・セントラルパーラー

・フラワーガーデン(ドトール)
3階

・第4会議室

・第5会議室 


\section{会場案内図}

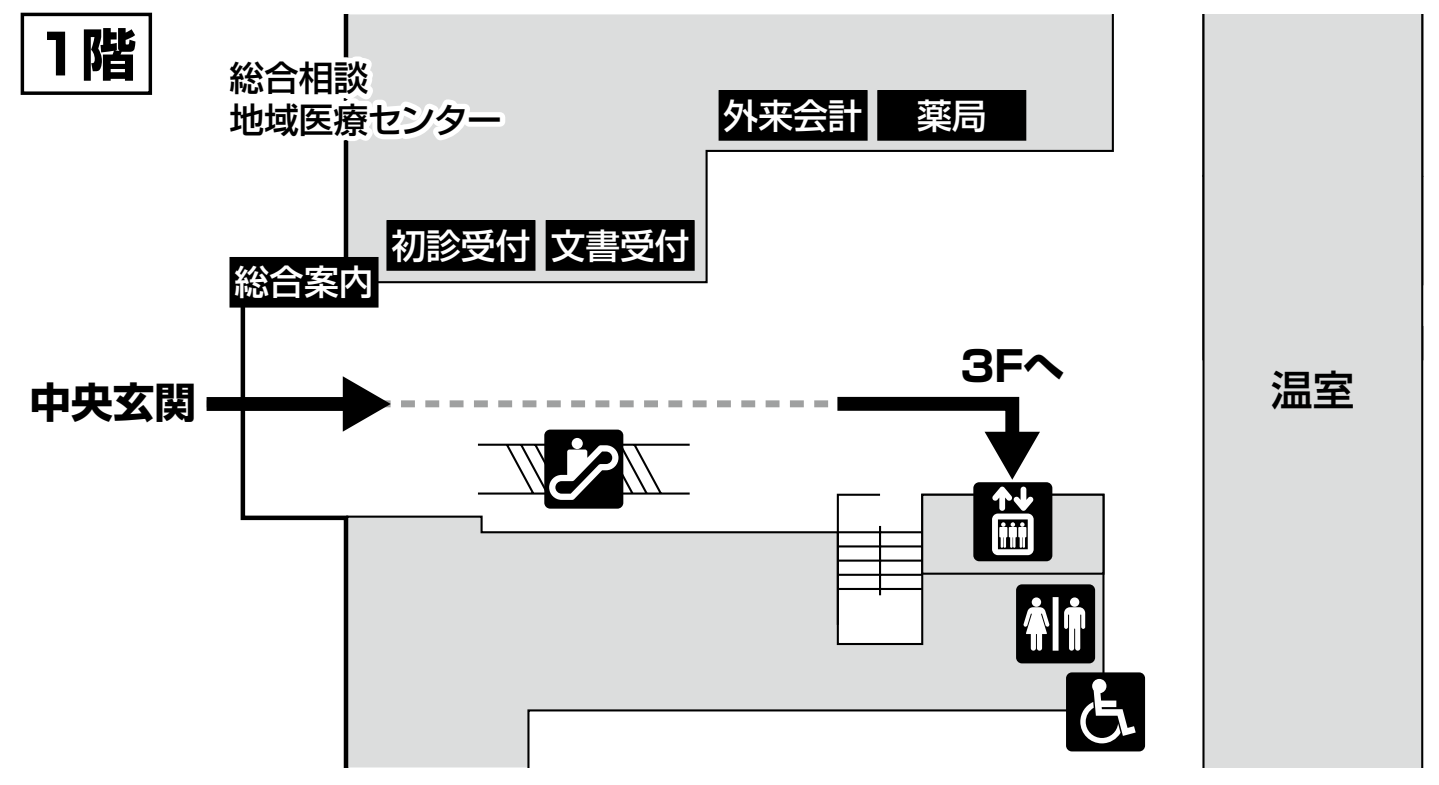

\section{3階}

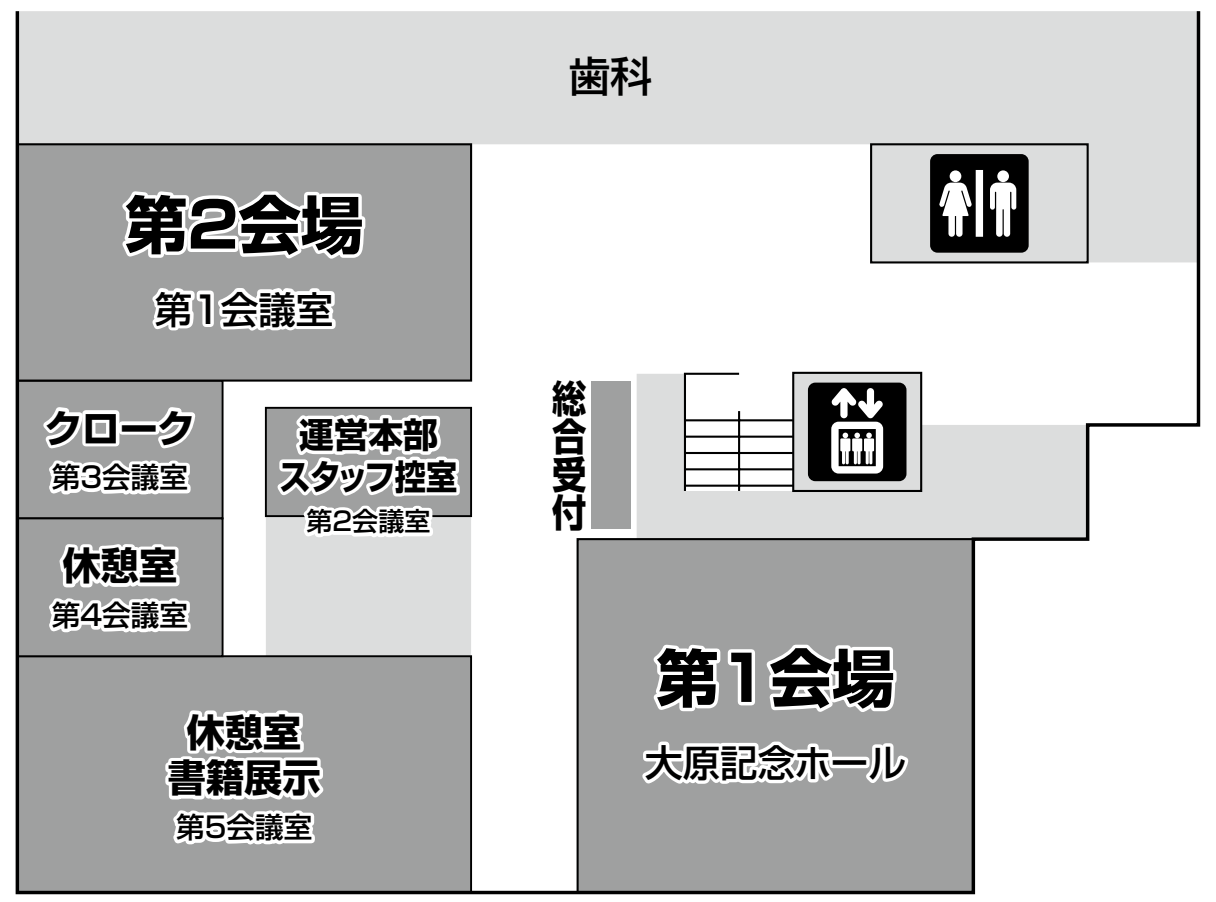


日程表

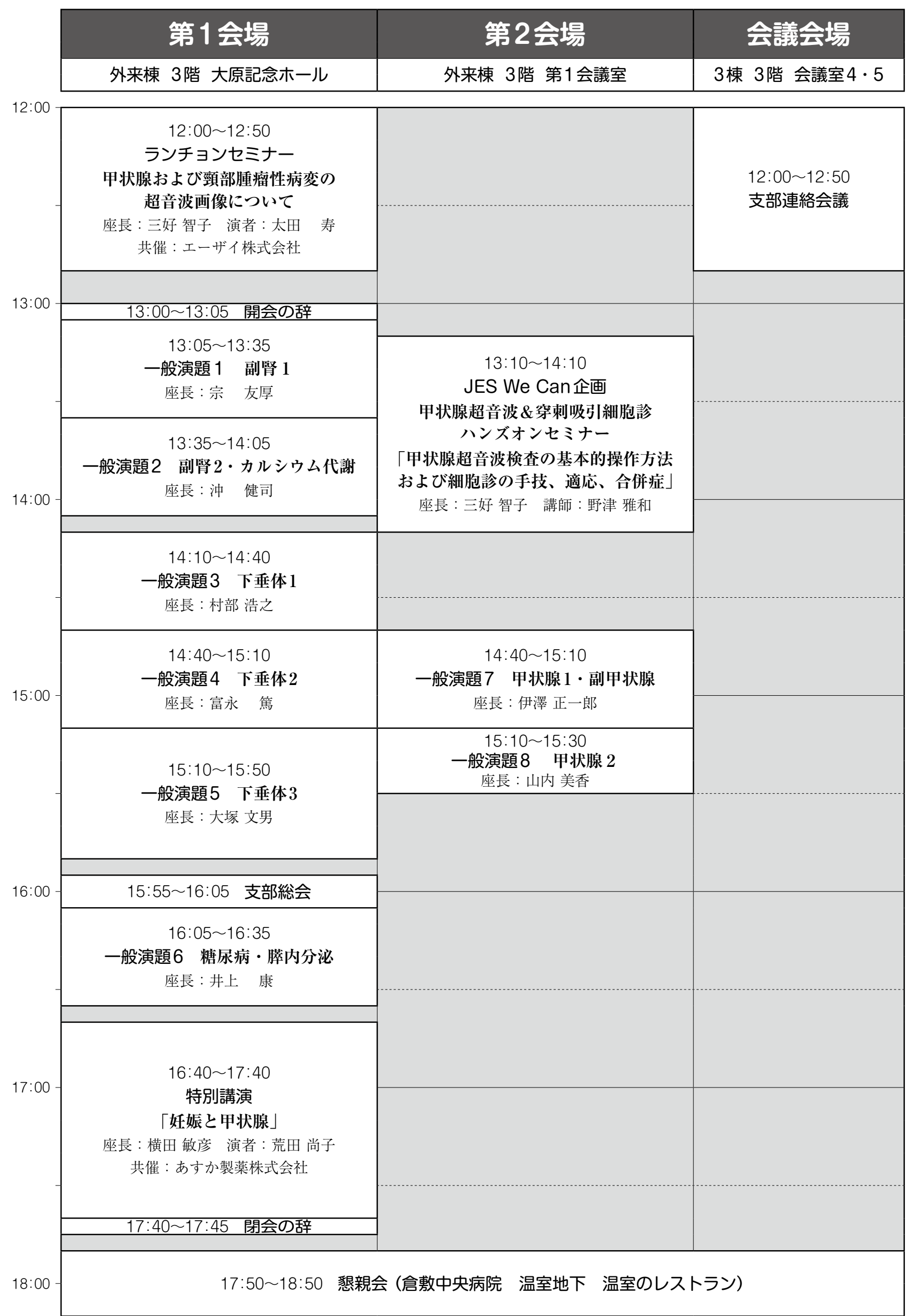




\section{第1会場（外来棟 3 階 大原記念ホール）}

座長：三好 智子（岡山大学医療教育統合開発センター）

「甲状腺および頸部腫瘤性病変の超音波画像について」

太田 寿医療法人神甲会郎病院 臨床検查科

共催：エーザイ株式会社

会長：横田 敏彦（公益財団法人 大原記念倉敷中央医療機構 倉敷中央病院 内分泌代謝・リウマチ内科)

01 ACTH非依存性大結節性副腎皮質過形成 (AIMAH)によるクッシング症候群の 1 例

○藤澤 諭, 稲垣 兼一, 西山 悠紀, 小松原 基志, 原 孝行, 細谷 武史, 当真 貴志雄, 越智 可奈子, 和田 淳, 大塚 文男

岡山大学病院 腎臓·糖尿病·内分泌内科/内分泌センター／総合内科

02 診断に至るまでに時間を要したRCC/PA/SCSを合併した1例

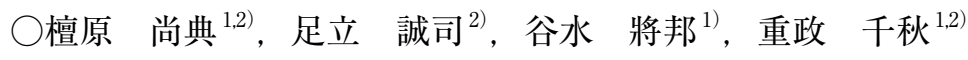

1)鳥取市立病院 内科, ${ }^{2)}$ 鳥取市立病院 総合診療科

$03{ }^{123}$ I-MIBG シンチグラフィ陽性副腎腺腫の一例

○武田 昌也 ${ }^{1)}$, 升田 碧 ${ }^{1)}$, 児島 亨 ${ }^{2)}$, 中塔 辰明 ${ }^{1)}$

1) 岡山済生会総合病院 糖尿病センター・内科, ${ }^{2)}$ 岡山済生会総合病院 外科 
04 左褐色細胞腫手術 10年後に右褐色細胞腫を指摘されMEN2Aが疑われる一例

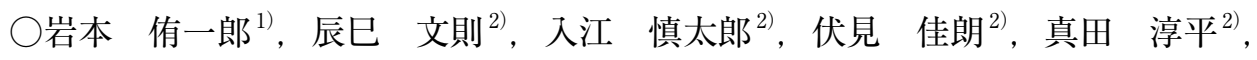

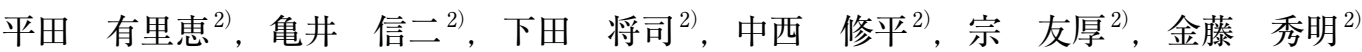
1)川崎医科大学附属病院 臨床教育研修セン夕-, ${ }^{2)}$ 川崎医科大学 糖尿病 - 代謝 · 内分泌内科学

05 末期腎不全に褐色細胞腫を合併した1 例 〜術前循環動態管理の考察〜

○岡本 健太郎, 伊藤 慶彦, 川島 彰透, 天野 綾, 岡㟝 恭子, 村部 浩之, 横田 敏彦 公益財団法人 大原記念倉敷中央医療機構 倉敷中央病院 内分泌代謝・リウマチ内科

06 高Ca血症クリーゼを契機に診断された多発性骨䯣腫の2例

$\bigcirc$ 伊藤 慶彦 $^{1)}$, 岡本 健太郎 ${ }^{1)}$, 川島 彰透 $^{1)}$, 天野 綾 $^{1)}$, 浜松 圭太 ${ }^{21}$, 岡㟝 恭子 ${ }^{1)}$, 山田 豪 $^{3)}$, 村部 浩之 ${ }^{1)}$, 横田 敏彦 ${ }^{1)}$

1) 公益財団法人 大原記念倉敷中央医療機構 倉敷中央病院 内分泌代謝・リウマチ内科,

${ }^{2)}$ 京都大学大学院 糖尿病. 内分泌・栄養内科学, ${ }^{3)}$ 医療法人和光会 山田病院

\section{7 先端巨大症手術後に残存した睡眠呼吸障害に対してCPAP導入を行った2例}

$\bigcirc$ 松田 枝里子 ${ }^{1)}$ ，伊澤 正一郎 ${ }^{2)}$, 松本 和久 ${ }^{2)}$, 藤山 美里 ${ }^{1)}$, 松澤 和彦 ${ }^{3)}$, 大倉 毅 ${ }^{2}$,

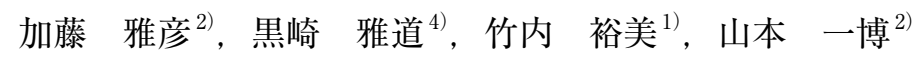

${ }^{1)}$ 鳥取大学医学部 感覚運動医学講座耳鼻咽喉・頭頸部外科学分野,

2) 鳥取大学医学部 病態情報内科学分野, ${ }^{3}$ 鳥取大学医学部 地域医療学講座,

4) 鳥取大学医学部 脳神経外科学分野

08 術後に衝動性の改善がみられた先端巨大症の一例

○真鍋 奈緒子 ${ }^{1)}$, 野津 雅和 $^{1)}$, 守田 美和 $^{1)}$, 金沢 一平 ${ }^{1)}$, 山本 昌弘 ${ }^{1)}$, 山内 美香 ${ }^{1)}$, 杉本 利嗣 ${ }^{1)}$, 山下 智子 ${ }^{2)}$

${ }^{1)}$ 島根大学医学部 内科学講座内科学第一, ${ }^{2}$ 島根大学医学部附属病院 精神科神経科

\section{9 先端巨大症の早期発見 一現状と課題一}

○下 康之 $^{1)}$, 富永 篤 ${ }^{2)}$, 碓井 智 ${ }^{1)}$, 有田 和徳 ${ }^{3}$, 迫口 哲彦 ${ }^{2)}$, 栗栖 薰 ${ }^{1)}$

1) 広島大学大学院医歯薬保健学研究院 脳神経外科学, ${ }^{2}$ ) 県立広島病院 脳神経外科,

${ }^{3)}$ 鹿児島大学大学院医歯学総合研究科 脳神経外科 
10 若年高血圧患者の脳出血発症を契機に診断したクッシング病の一例

○秋山 優, 近藤 学, 幡中 雅行, 竹田 孔明, 谷澤 幸生 山口大学医学部附属病院 第三内科

11 Cushing 病診断における海綿静脈洞サンプリングの有用性 $\bigcirc$ 迫口 哲彦, 富永 篤, 竹下 真一郎, 岐浦 禎展, 籬 拓郎, 近藤 浩, 川住 知弘 県立広島病院 脳神経外科・脳血管内治療科

\section{2 プロラクチン分泌能の低いプロラクチノーマが疑われる1例}

○野津 雅和, 三宅 仁美，守田 美和，金沢 一平，山本 昌弘，山内 美香，杉本 利嗣 島根大学医学部 内科学講座内科学第一

13 進行性の低Na血症を契機に産裖早期に診断し得たSheehan症候群の1例

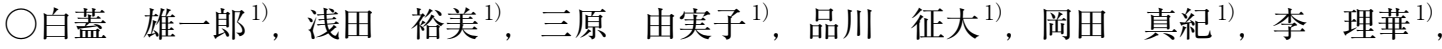

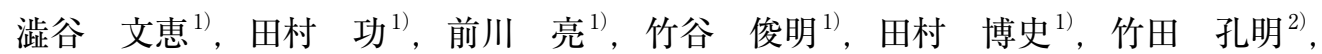
谷澤 幸生 $^{2)}$, 杉野 法広 $^{1)}$

${ }^{1)}$ 山口大学医学部附属病院 産科婦人科, ${ }^{2)}$ 山口大学医学部附属病院 第三内科

\section{4 難産での出産後に発症した下垂体機能低下症の1例}

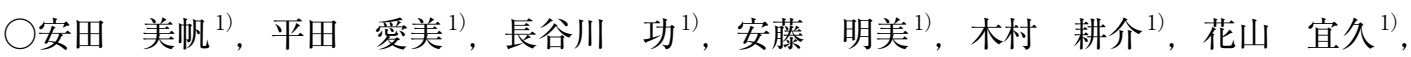

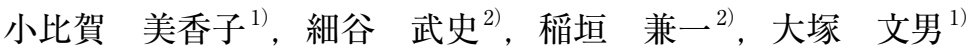

${ }^{1)}$ 岡山大学病院 総合内科, ${ }^{2)}$ 岡山大学病院 内分泌センター

\section{5 中枢性尿崩症と骨䯣異形成症候群を合併した1例}

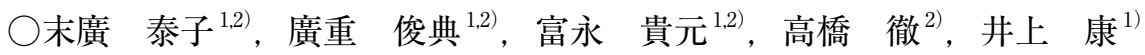

1) 山口県立総合医療センター 内分泌内科, ${ }^{2)}$ 山口県立総合医療センタ一 血液内科

\section{6 糖尿病増悪と多尿を契機に診断に至つたIgG4関連下垂体炎の1例}

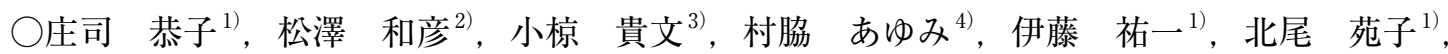
松本 和久 $^{1)}$, 中村 理沙 $^{1)}$, 角 啓佑 ${ }^{1)}$, 藤岡 洋平 ${ }^{1)}$, 伊澤 正一郎 ${ }^{1)}$, 大倉 毅 ${ }^{1)}$,

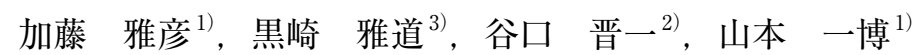

1) 鳥取大学医学部 病態情報内科, ${ }^{2}$ 鳥取大学医学部 地域医療学講座, ${ }^{3)}$ 鳥取大学医学部 脳神経外科,

4) 鳥取県立厚生病院 内科 
17 数年の経過でインスリン依存状態となったZnT8抗体陽性 1 型糖尿病の1例

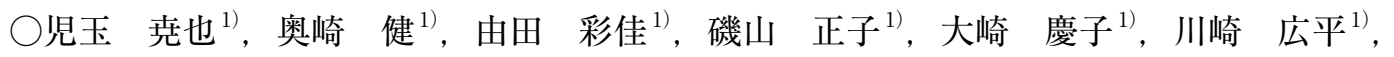
米田 真康 $^{22}$

${ }^{1)}$ 三原市医師会病院, ${ }^{21}$ 広島大学大学院分子内科学 内分泌・糖㽷病内科

18 SGLT2 阻害薬の安全かつ効果的な使用方法の検討

○岩田 康義, 次田 誠

独立行政法人 労働者健康福祉機構 香川労災病院 内科

19 SACIテストにおける擬陽性を排除し腫瘍局在を診断し得たインスリノーマの 1 例

○梶川 隆治郎, 江草 玄太郎, 久保田 益亘, 大久保 博史, 大野 晴也, 沖 健司, 米田 真康

広島大学病院 内分泌 $\cdot$ 糖尿病内科

16:40 17:40 特別講演

第1会場

座長：横田 敏彦（公益財団法人 大原記念倉敷中央医療機構 倉敷中央病院 内分泌代謝・リウマチ内科）

「妊娠と甲状腺」

荒田 尚子 国立研究開発法人 国立成育医療研究センター

周産期・母性診療センタ一内科 母性内科

共催：あすか製薬株式会社

会長：横田 敏彦（公益財団法人 大原記念倉敷中央医療機構 倉敷中央病院 内分泌代謝・リウマチ内科) 
甲状腺超音波＆穿刺吸引細胞診 ハンズオンセミナー

「甲状腺超音波検查の基本的操作方法および細胞診の手技、適応、合併症」

野津 雅和 島根大学医学部 内科学講座内科学第一

穿刺指導 :

[交差法］野津 雅和（島根大学医学部 内科学講座内科学第一）

[平面法] 溝尾 妙子 (渡辺病院外科/岡山大学病院 乳腺 - 内分泌外科)

[平面法·ガイドあり·ピストルあり]

天野 綾（公益財団法人 大原記念倉敷中央医療機構 倉敷中央病院 内分泌代謝・リウマチ内科）

20 当院で経験した甲状腺髄様癌の超音波所見の検討

黑木 梨沙 $^{1)}$, 佐原 朗子 $^{1)}$, 吉本 理紗 $^{1)}$, 久安 莉加 ${ }^{1)}$, 石井 雄也 ${ }^{1)}$, 山内 陽平 ${ }^{1)}$,

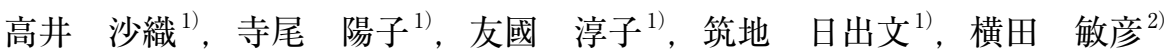

1) 公益財団法人 大原記念倉敷中央医療機構 倉敷中央病院 臨床検査技術部,

2) 公益財団法人 大原記念倉敷中央医療機構 倉敷中央病院 内分泌代謝・リウマチ内科

21 甲状腺濾胞性腫瘍の超音波診断：Real-time Tissue Elastographyを用いた 検討

【コメディカル演題】

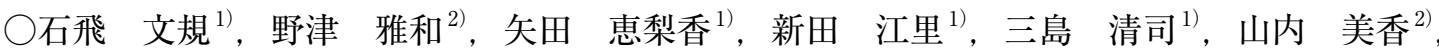
杉本 利嗣 ${ }^{2)}$, 石川 典由 ${ }^{3)}$, 長井 篤 ${ }^{1)}$

1)島根大学医学部附属病院 検査部, ${ }^{2)}$ 島根大学医学部 内科学講座内科学第一,

3) 島根大学医学部附属病院 病理部

22 当院での原発性副甲状腺機能六進症 40例における超音波検査の副甲状腺検出 率の検討

【コメディカル演題】

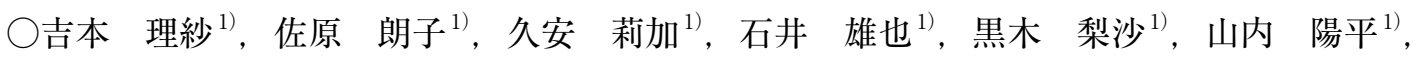
高井 沙織 ${ }^{1)}$, 寺尾 陽子 ${ }^{1)}$, 友國 淳子 ${ }^{1)}$, 筑地 日出文 ${ }^{1)}$, 横田 敏彦 ${ }^{2)}$

1) 公益財団法人 大原記念倉敷中央医療機構 倉敷中央病院 臨床検査技術部

2) 公益財団法人 大原記念倉敷中央医療機構 倉敷中央病院 内分泌代謝・リウマチ内科 
23 甲状腺穿刺吸引細胞診「鑑別困難」症例の再評価

○遠藤 由香利 ${ }^{1)}$, 大野 千恵子 ${ }^{1)}$, 松重 貴大 $^{1)}$, 持田 洋利 ${ }^{1)}$, 山田 恭子 ${ }^{1)}$,

伊澤 正一郎 ${ }^{2)}$, 松澤 和彦 ${ }^{2)}$, 福原 隆宏 ${ }^{3)}$, 覚道 健一 ${ }^{4)}$, 梅北 善久 ${ }^{1)}$

1) 鳥取大学医学部附属病院 病理部, ${ }^{2}$ 鳥取大学医学部 病態情報内科学分野,

3) 鳥取大学医学部 感覚運動医学講座耳鼻咽喉・頭頸部外科学分野,

4) 近畿大学医学部奈良病院 臨床検査部

24 充実性成分を有する甲状腺癌の細胞像

○原田 美香 ${ }^{1)}$, 香田 浩美 ${ }^{1)}$ ，小寺 明美 ${ }^{1)}$ ，山口 大介 ${ }^{1)}$, 内野 かお放 ${ }^{2)}$, 能登原 憲司 ${ }^{2)}$

1) 公益財団法人 大原記念倉敷中央医療機構 倉敷中央病院 臨床検査技術部 病理検查室,

2) 公益財団法人 大原記念倉敷中央医療機構 倉敷中央病院 病理診断科

17:50～18:50 贸親会 （倉敷中央病院 温室地下 温室のレストラン） 
抄

録 


\title{
妊娠と甲状腺
}

\author{
荒田 尚子 \\ 国立研究開発法人 国立成育医療研究センター 周産期・母性診療センタ一内科 母性内科
}

甲状腺疾患は妊娠可能年齢に多くみられることから、合併妊娠に対応すべき機会は多い。妊娠 中の E2 増に伴い血中の総 $\mathrm{T} 4$ 值は妊娠 15 週までに約 $1.3 \sim 1.5$ 倍に増加する。また、妊娠 10 週をピー クとした胎盤由来の hCGによる甲状腺刺激で妊娠初期 fT4 值は軽度上昇し、妊娠中後期は非妊娠 時の基準值に比較して低值を示す。妊娠初期にみられる甲状腺機能立進症では、バセドウ病と一 般妊婦の 2 ～ $3 \%$ にみられる妊娠性一過性甲状腺機能立進症との鑑別が重要で、TSH受容体抗体 (TRAb) の測定が有用である。

未治療やコントロール不十分なバセドウ病の場合は、流早産、死産、胎児発育遅延、妊娠高血 圧症候群、心不全、新生児甲状腺機能異常等のリスクが一般妊婦に比較して高く、妊娠前の適切 な治療によりそのリスクを軽減できる。抗甲状腺薬は 2 種類で、プロピルチオウラシル (PTU) よ りチアマゾール (MMI) が効果や副作用の点では明らかに優れているが、MMIの催奇形性 (臍腸管 遺残や臍帯へルニア、食道閉鎖、後鼻孔閉鎖、頭皮欠損等)のために、妊娠初期、特に妊娠 5 週か ら 9 週の MMI内服は可能な限り回避する必要がある。また、胎児の甲状腺は $18 〜 20$ 週以降にその 機能がほぼ完成することから、妊娠後半は胎児へのTRAbと抗甲状腺薬や無機ヨウ素の影響の両 者を考える必要がある。妊娠後半になっても TRAbが $10 \mu \mathrm{IU} / \mathrm{mL}$ 以上か TSAb が強陽性の場合は 新生児甲状腺機能立進症の可能性を考慮し、新生児科医や小児科医との連携を行う。

潜在性甲状腺機能低下症 (SCH) と流早産などの妊娠転帰および甲状腺自己免疫と流早産との関 連性が明らかになり、不妊や反復流産既往の女性あるいは妊娠女性に対し甲状腺ホルモンのスク リーニングが行われ始めている。顕性甲状腺機能低下症は甲状腺自己抗体の有無にかかわらず流 早産等の妊娠リスクが高く、介入の有用性も明らかであることから、十分なレボチロキシン (LT4) 投与を行う。甲状腺自己抗体陽性の場合は、TSH值が $2.5 \mu \mathrm{IU} / \mathrm{mL}$ 以上の $\mathrm{SCH}$ であれば流早産など のリスクが高く、介入がそのリスクを軽減させるので十分なLT4投与を行う。甲状腺自己抗体陽 性かつ甲状腺機能正常、甲状腺自己抗体陰性かつ TSH值が $2.5 \mu \mathrm{IU} / \mathrm{mL}$ 以上のSCH の場合は流産な どの何らかの妊娠リスクは予想されるが、介入の有用性を示す証拠は十分とはいえないことから、 症例毎にLT4投与を行うかの検討が必要である。 


\title{
甲状腺超音波＆穿刺吸引細胞診ハンズオンセミナー 「甲状腺超音波検査の基本的操作方法および細胞診の手技、適応、合併症」
}

\author{
講師：野津 雅和（島根大学医学部 内科学講座内科学第一） \\ 座 長 : 三好 智子（岡山大学医療教育統合開発センター） \\ 穿刺指導 : [交差法] 野津 雅和（島根大学医学部 内科学講座内科学第一） \\ [平面法] 溝尾 妙子（渡辺病院外科／岡山大学病院 乳腺·内分泌外科） \\ [平面法·ガイドあり·ピストルあり] \\ 天野 綾（公益財団法人 大原記念倉敷中央医療機構 倉敷中央病院 \\ 内分泌代謝・リウマチ内科）
}

甲状腺超音波検査を用いることにより、簡易かつ非侵襲的に甲状腺疾患の評価を行うことがで きる。一方で近年、様々な画像検査の進歩により、年々甲状腺疾患の発見数が増加している。こ のため、超音波検査技師や診断医には、甲状腺疾患の超音波診断技術に加え、そのマネージメン 卜に関する知識が求められている。本企画では、甲状腺超音波の基本的操作方法に加え、先日公 表された日本乳腺甲状腺超音波診断会議による穿刺細胞診の適応、穿刺すべきでない病変、そし て合併症とその対策について解説を行う。穿刺細胞診の必要物品や方法について解説したのち、 交差法、同一平面法の穿刺手技についてハンズオンセミナーを行う。 


\section{ACTH非依存性大結節性副腎皮質過形成 (AIMAH) による クッシング症候群の1例}

○藤澤 諭, 稲垣 兼一, 西山 悠紀, 小松原 基志, 原 孝行,

細谷 武史, 当真 貴志雄, 越智 可奈子, 和田 淳, 大塚 文男

岡山大学病院 腎臓・糖尿病 · 内分泌内科/内分泌センター／総合内科

症例は 50 代女性。既往歴に甲状腺乳頭癌術後、腰椎圧迫骨折 (3年前)。数 年前から両下腿浮腫のため近医にて利尿剂で加療されていたが、今回右下腿 に蜂窩織炎、皮膚潰瘍が出現した。皮膚潰瘍が遷延し精査したところCTにて 両側副腎腫大を認め当院紹介となった。満月様顔貌、中心性肥満などクッシ ング兆候を示し、高血圧、著明な高血糖（HbA1c 11.4\%）を認めた。ACTH < $1.0 \mathrm{pg} / \mathrm{ml}$, 血清コルチゾール $42.2 \mu \mathrm{g} / \mathrm{dl}$, 尿中フリーコルチゾール $466.2 \mu \mathrm{g} /$ dayと上昇を認め、コルチゾールの日内変動は消失し $1 \mathrm{mg}$ デキサメサゾン 試験にて抑制されなかった。CTにて両側副腎に複数の結節性病変を認め、 MRI 上opposed phaseでの信号低下があり AIMAHに合致した所見であった。 I131-アドステロールシンチでは両側性 (右>左)に高集積を認めた。以上より AIMAHによるクッシング症候群と診断した。入院時よりD-ダイマー、FDP の上昇を認め入院後低酸素血症、肺血栓塞栓症を来たし、IVCフィルター留 置と抗凝固療法を要した。全身状態より外科的副腎切除が困難であったため、 メチラポンを少量より開始し、ヒドロコルチゾンによる補充と共に $1500 \mathrm{mg} /$ 日まで増量し、高コルチゾール血症をコントロールした。AIMAHでは様々な 程度のコルチゾール分泌過唾を認めることが知られ根治療法は両側副腎摘出 であるが、近年副腎のサイズやアドステロールシンチ集積の程度から優位側 のみを切除する片側摘出術の有用性も多く報告される。高コルチゾール血症 が顕著な症例では感染症、凝固異常など種々の合併症で手術困難なケースも 存在し個々の症例に応じた治療を考慮する必要があると考えられた。 
$\bigcirc$ 檀原 尚典 ${ }^{1,2)}$, 足立 誠司 ${ }^{2)}$, 谷水 將邦 $^{1)}$, 重政 千秋 ${ }^{1,2)}$

${ }^{1)}$ 鳥取市立病院 内科， ${ }^{2)}$ 鳥取市立病院 総合診療科

症例は 43歳女性。頭痛/倦总感を主訴に受診。高血圧 $(169 / 106 \mathrm{mmHg}) /$ 左 副腎腫瘤 (25mm大) あり紹介。血漿アルドステロン濃度 (PAC) $182.8 \mathrm{pg} / \mathrm{ml}$ 、 血漿レニン活性 (PRA) 0.2ng/ml/h から原発性アルドステロン症 (PA) 疑い。 ACTH $4.5 \mathrm{pg} / \mathrm{ml}$ 、Cortisol (F) $8.3 \mu \mathrm{g} / \mathrm{dl}$ は経過観察としていた。PA機能確認 検査は陽性。ACTH負荷副腎静脈サンプリング (AVS) での PAC/F は右副腎 静脈: 35559.9/105.9、左副腎静脈：17671.9/521.6、下大静脈：443.6/12.47で、 lateralized ratio (9.91)/contralateral ratio (0.95) は右アルドステロン産生腺腫 (APA) を思わせたが、PAC 絶対值の両側高值は両側 APA/非機能性副腎腺腫 合併特発性アルドステロン症も考慮された。この時 $\mathrm{F} の$ 左右差を右副腎静脈 へのカニュレーションの問題と判断していた。AVS後選択的アルドステロン 拮抗薬 $(\mathrm{SAB})$ 等開始し、降圧するも主訴持続。頭痛精査でラトケ囊胞 (RCC) 発覚。囊胞径 (3mm大) や MRI所見 (T1 低信号) からは頭痛/内分泌障害を呈 するとは考えにくかったが、愁訴強く下垂体前葉機能検査施行。正常反応で あったが、ACTH基礎值は8.4(F 9.2) と低值。この時点で改めてdataを見直し、 $\mathrm{ACTH}$ 值や AVS 時の F 左右差、左副腎腫瘍径等から、サブクリニカルクッシ ング症候群 (SCS) の存在を疑った。F日内リズム消失及び自律性分泌を確認。 副腎シンチグラフィで左集積立進/右抑制あり、SCS と診断。PA/SCS 合併は 近年多数報告例があり、常に念頭に入れるべきである(本例でもそれに気づく pointは幾度もあった)。またRCC 発見時も愁訴に翻弄され負荷試験まで施行 した事も猛省すべきであった。今後左副腎切除 (+SAB等での降圧)を計画し ているが、治療方針につき、この場を借りて相談させていただきたい。 


\section{${ }^{123}|-M| B G$ シンチグラフィ陽性副腎腺腫の一例}

$\bigcirc$ 武田 昌也 ${ }^{1)}$, 升田 碧 ${ }^{1)}$, 児島 亨 ${ }^{2)}$, 中塔 辰明 ${ }^{1)}$

${ }^{1)}$ 岡山済生会総合病院 糖尿病センター・内科, ${ }^{2)}$ 岡山済生会総合病院 外科

症例は 60 歳代男性。腎孟尿管移行部狭窄症の既往あり泌尿器科で加療中、 左副腎腫大と血中カテコールアミン濃度高值のため当科紹介となった。発作 性の血圧上昇のエピソードあり。採血ではアドレナリン $46 \mathrm{pg} / \mathrm{mL}$ 、ノルアド レナリン $1262 \mathrm{pg} / \mathrm{mL}$ (基準 100-450)、ドーパミン $27 \mathrm{pg} / \mathrm{mL}$ とノルアドレナリ ンの正常上限 3 倍弱の上昇を認めた。CTで左副腎に $16 \times 14 \mathrm{~mm}$ の結節を認 めた。1年前のCTと比較し増大傾向なし。低吸収でありCT所見からは腺腫 が疑われた。MRIでは内部に脂肪は確認できず、T2強調画像での高信号も認 めず、質的診断は困難であった。 ${ }^{123} \mathrm{I}-\mathrm{MIBG}$ シンチグラフィを施行したところ SPECT/CT 画像で当該結節に高集積を認め、左副腎褐色細胞腫と術前診断し た。外来でドキサゾシンを導入し $4 \mathrm{mg} /$ 日内服下において腹腔鏡下左副腎切 除術を施行した。術中に著明な血圧変動は認めなかった。切除した副腎の割 面は皮質の暗褐色部分が結節状に腫大し、組織所見も淡明な細胞質の副腎皮 質細胞が結節性に増殖する像を呈した。一部に髄質細胞の過形成を認めるも 全体としては副腎皮質の増殖が主病変と考え、副腎皮質腺腫と術後診断した。 MIBG (metaiodobenzylguanidine) はその構造がノルエピネフリンと類似して おり褐色細胞腫に取り达まれるため ${ }^{123}$ I標識 MIBG シンチグラフィは褐色細胞 腫の機能的局在診断に用いられる。感度・特異度ともに高い検査ではあるが、 少ないながらも偽陽性例の報告がみられる。興味深い症例と考えられたので 報告する。 


\section{左褐色細胞腫手術 10年後に右褐色細胞腫を指摘されMEN2A が疑われる一例}

○岩本 侑一郎 ${ }^{1)}$, 辰巳 文則 ${ }^{2)}$, 入江 慎太郎 ${ }^{2)}$, 伏見 佳朗 $^{22}$,

真田 淳平 $^{2)}$, 平田 有里恵 ${ }^{2)}$, 亀井 信二 ${ }^{2)}$, 下田 将司 ${ }^{2)}$,

中西 修平 $^{2}$, 宗 友厚 ${ }^{2)}$, 金藤 秀明 ${ }^{2)}$

1)川崎医科大学附属病院臨床教育研修センター,

2)川崎医科大学 糖尿病 ·代謝 · 内分泌内科学

【症例】41歳、男性

【主訴】動悸、易疲労感

【現病歷】2004年の健診で高血圧を指摘されたが放置。2006年に近医を受診し たところ、左副腎褐色細胞腫と診断され、腹腔鏡下左副腎摘出術を施行。経 過良好であり2011年に通院を自己中断。2016年健診で肝機能異常を指摘され 当院受診。腹部超音波検查で右副腎腫大を指摘され、CT、MRI検查で右副腎 に39 × 34mmの腫瘍があり、 ${ }^{123} \mathrm{I}-\mathrm{MIBG}$ シンチグラフィで同部位に集積があり、 当科を紹介。血中アドレナリン (A) 278、ノルアドレナリン (NA) 419、ドーパ ミン $(\mathrm{DA}) \leqq 5 \mathrm{pg} / \mathrm{mL}$ 、蓄尿中 A 181.9、NA 249.9、DA $1642.2 \mu \mathrm{g} / \mathrm{day}$ 、メ夕 ネフリン 2.55 、ノルメタネフリン $0.87 \mathrm{mg} / \mathrm{day}$ であり、褐色細胞腫と診断した。 また、父方叔父 2 人に甲状腺髄様癌 (1 人は褐色細胞腫も)、従妹に褐色細胞腫 の家族歴あり。甲状腺超音波検查で $5 \times 5 \mathrm{~mm}$ 、辺縁不整、内部不均一の腫藘 があり、CEA は正常範囲内であるがカルチトニン $27.9 \mathrm{pg} / \mathrm{mL}$ と高值。 $\mathrm{Ca}$ ・副 甲状腺系の異常はなく、2B を疑う特徵的な身体所見もないことから MEN2A が強く疑われる。ドキサゾシンによる術前ブロックを開始した。褐色細胞腫 術後に甲状腺腫瘤に対する穿刺吸引細胞診掞よび遺伝子診断を予定している。 【考察】MEN2 はRET 遺伝子を原因遺伝子とする内分泌疾患である。一般的に は甲状腺䯣様癌が先行し発見されることが多いが、時期を隔てて発症した両 側副腎褐色細胞腫を契機にMEN2Aが疑われる一例を経験したため報告する。 


\section{末期腎不全に褐色細胞腫を合併した1例 〜術前循環動態管理 の考察〜}

○岡本 健太郎, 伊藤 慶彦, 川島 彰透, 天野 綾, 岡㟝 恭子,

村部 浩之, 横田 敏彦

公益財団法人 大原記念倉敷中央医療機構 倉敷中央病院 内分泌代謝・リウマチ内科

【症例】53歳女性。2002年、ループス腎炎による末期腎不全で血液透析導入。 2015年、透析関連腎癌スクリーニング目的の腹部 CT で右副腎腫瘍（径 $30 \mathrm{~mm}$ ) を認め、半年後に軽度増大あり当科紹介。血圧 $175 / 109 \mathrm{mmHg}$ (降圧薬なし)。 血中アドレナリン (A) $500 \mathrm{pg} / \mathrm{ml}$ 、ノルアドレナリン (NA) $2626 \mathrm{pg} / \mathrm{ml}$ と高値 で、clonidineによる抑制を認めなかった。I-123 MIBGシンチグラフィで右 副腎腫瘍に取込みを認めたことから右副腎褐色細胞腫と診断、後腹膜鏡下右 副腎摘除術を予定した。術前の循環動態管理目的で手術 2 週間前に入院し、 doxazosin $1 \mathrm{mg} /$ day から $8 \mathrm{mg} /$ day まで漸増した。透析時に血圧低下を認め、 ドライウェイト (DW)を最終的に $1.5 \mathrm{~kg}$ 増加させて対応した。術中に収縮期血 圧 $250 \mathrm{mmHg}$ 以上となり nicardipine の間歇/持続静注 (合計 $3.0 \mathrm{mg}$ ) を要した が、腫瘍摘出後は収縮期血圧 $120 \mathrm{mmHg}$ 程度で推移しカテコラミンは不要で あった。術後、血中 A $39 \mathrm{pg} / \mathrm{ml} 、 \mathrm{NA} 190 \mathrm{pg} / \mathrm{ml}$ と正常化し、24時間血圧測定 の平均值 94/53mmHg と血圧も改善した(降圧薬なし)。一方 DW は術直前よ り更に0.5kg 増加したが、心胸郭比などから適正な体液量と考元られた。

【考案】褐色細胞腫の術前管理では $a$ 遮断薬を中心とした降圧療法に加え、減 少した循環血漿量是正のため術直前には $1 \sim 2 \mathrm{~L} / \mathrm{day}$ の電解質輸液を行う（褐 色細胞腫診療指針 2012)。透析患者ではDW の調節で循環血漿量を管理するこ とになり、褐色細胞腫術前にDWをどう設定すべきか定まった見解はないも のの、増加させて管理した報告が多い。今回 DWを $1.5 \mathrm{~kg}$ 増加させることで良 好に管理しえた症例を経験した。透析患者における褐色細胞腫術前の循環動 態管理について文献的考察を交えて報告する。 


\section{高Ca血症クリーゼを契機に診断された多発性骨髄腫の2例}

$\bigcirc$ 伊藤 慶彦 ${ }^{1)}$, 岡本 健太郎 ${ }^{1)}$, 川島 彰透 ${ }^{1)}$, 天野 綾 $^{1)}$, 浜松 圭太 $^{21}$,

岡㟝 恭子 ${ }^{1)}$, 山田 豪 $^{3)}$, 村部 浩之 ${ }^{1)}$, 横田 敏彦 ${ }^{1)}$

1) 公益財団法人 大原記念倉敷中央医療機構 倉敷中央病院 内分泌代謝・リウマチ内科,

2) 京都大学大学院 糖尿病· 内分泌 $\cdot$ 栄養内科学, ${ }^{3)}$ 医療法人和光会 山田病院

【症例 1】74歳女性。当院受診 2 ケ月前に腰椎圧迫骨折で前医入院、骨粗鬆症の 診断でテリパラチド皮下注と L-アスパラギン酸 Ca内服を開始された。治療前 の血清補正 $\mathrm{Ca}$ 值 $(\mathrm{cCa})$ は $10.5 \mathrm{mg} / \mathrm{dl}$ であった。入院後に胸部痛、背部痛を認 めた。その後意識レベルが低下し、cCa $14.9 \mathrm{mg} / \mathrm{dl}$ と上昇認めたため当院へ救 急搬送された。救急受診時GCS : E3V3M4。ICUに入室して緊急透析、生理 食塩水負荷、フロセミド静注、エルカトニン静注を行った。CTで全身に打ち 抜き状の溶骨性病变と多発病的骨折あり、骨髄穿刺で多発性骨髄腫と診断し た。PTHrPは $1.6 \mathrm{pmol} / 1$ と軽度上昇に留まっていた。第3病日にデキサメタゾ ン $(\mathrm{DEX})+$ デノスマブ投与開始し、第4 病日 cCa $10.6 \mathrm{mg} / \mathrm{dl}$ まで低下したが意 識障害は遷延した。全身状態は改善せず、第 13 病日に永眠された。

【症例 2】77歳男性。当院受診 2 ヶ月前に腰痛出現し、近医にて腰椎圧迫骨折と 診断され、エルカトニン筋注が行われたが症状は改善しなかった。ADL低下 進行し、起立困難となり当院へ救急搬送された。搬送時GCS：E4V4M6。cCa $13.8 \mathrm{mg} / \mathrm{dl}$ であり生理食塩水負荷、エルカトニン静注、ゾレドロン酸静注、血 液透析が施行されたが高Ca血症は持続した。血清・尿免疫電気泳動でB-J蛋 白 $\kappa$ 型検出され、骨髄穿刺で多発性骨髄腫と診断した。PTHrPは $1.0 \mathrm{pmol} / 1$ 以 下と低值であった。第8病日よりDEX投与開始、一旦病態改善が見られたが、 その後腎機能低下が増悪した。ボルテゾミブ+DEX投与開始するも病態は改 善無く、第 65 病日に永眠された。

【考察】 2 例とも入院早期に診断に至ったが、既に多臓器不全を合併しており救 命は困難であった。骨病変の診療においては血清 $\mathrm{Cr}$ 值の確認と病態の把握が 不可欠と考えられる。 


\section{先端巨大症手術後に残存した睡眠呼吸障害に対してCPAP 導入を行つた2例 \\ 【コメディカル演題】}

$\bigcirc$ 松田 枝里子 ${ }^{1)}$, 伊澤 正一郎 ${ }^{2)}$, 松本 和久 ${ }^{2)}$, 藤山 美里 ${ }^{1)}$,

松澤 和彦 ${ }^{3)}$, 大倉 毅 $^{2)}$, 加藤 雅彦 $^{2)}$, 黑崎 雅道 $^{4)}$, 竹内 裕美 $^{1)}$, 山本 一博 ${ }^{2}$

${ }^{1)}$ 鳥取大学医学部 感覚運動医学講座 耳鼻咽喉 · 頭頸部外科学分野,

2) 鳥取大学医学部 病態情報内科学分野, ${ }^{3)}$ 鳥取大学医学部 地域医療学講座,

4) 鳥取大学医学部 脳神経外科学分野

【はじめに】先端巨大症は軟部組織の肥厚や巨舌により、約 40～50\%で睡眠呼 吸障害 $(\mathrm{SDB})$ を合併するとされる。近年当院では経蝶形骨洞的下垂体腫瘍摘 出術前に終夜ポリソムノグラフィーによるSDBのスクリーニングを行ってお り、8例中 4 例で無呼吸低呼吸指数 (AHI) が $20 / \mathrm{h}$ 以上であった。術後も SDB が残存し、経鼻的持続陽圧呼吸療法 (CPAP) の適応となったのは3例で、その うちマスク選択に工夫を要した2例を報告する。

【症例 1】62歳男性。BMI は28.1、術後 AHI は60.5/hであった。鼻翼拡大によ りネーザルマスクとピロータイプは合わず、フルフェイスマスクで導入した が、高い圧力を要し本人の使用感が悪かった。様々なネーザルマスクを検討し、 唯一鼻翼が収まったものを使用しているが、リークの抑制が課題である。

【症例 2】65歳女性。BMI は28.1、術後 AHI は46.1/hであった。ネーザルマス クでは開口によるリークが疑われたが、フルフェイスマスクは本人の使用感 が悪く、現在はネーザルマスクにロテープを併用している。リークの抑制は 不十分だが、CPAPによって熟眠感が得られ日中の眠気も改善している。

【考察】先端巨大症の患者では、鼻翼拡大や下顎突出などの顔貌変化により使 用できるマスクが限られたり、咬合不全で口からリークする可能性もある。 CPAP導入の際には、豊富なマスクの中から患者に適したものを選定するこ とが重要と思われる。また導入後は医師と検査技師が連携してフォローアッ プし、問題点に対応していくことで長期に良好な治療コンプライアンスを得 ることが期待される。 
術後に衝動性の改善がみられた先端巨大症の一例

○真鍋 奈緒子 ${ }^{1)}$, 野津 雅和 $^{1)}$, 守田 美和 $^{1)}$, 金沢 一平 ${ }^{1)}$,

山本 昌弘 ${ }^{1)}$, 山内 美香 $^{1)}$, 杉本 利嗣 $^{1)}$, 山下 智子 ${ }^{2)}$

${ }^{1)}$ 島根大学医学部 内科学講座内科学第一, ${ }^{2}$ 島根大学医学部附属病院 精神科神経科

【症例】41歳 女性。幼少時から不注意であり、成人になり精神科にて注意欠陥 多動性障害と診断されアトモキセチン、セルトラリンを内服していた。25〜 30 歳の間に鼻翼の拡大など顔貌の変化が出現した。31歳時より衝動性の増加 と共に過食となり、体重が $90 \mathrm{~kg}$ から $115 \mathrm{~kg}$ 一と増加し当科紹介となった。特 徵的な顔貌、GH 3.3ng/mL、IGF-I 431ng/mL (+5.1SD)、OGTTでGH の抑制 がなく(底值 $1.6 \mathrm{ng} / \mathrm{mL})$ 、頭部 MRIにて巨大な下垂体腫瘍を認め先端巨大症 と診断した。プロラクチン (PRL) $31.0 \mathrm{ng} / \mathrm{mL}$ と軽度上昇あり、他の下垂体ホ ルモンは異常なし。経鼻的下垂体腫瘍摘出術を施行し、病理所見はGH および PRL 産生下垂体腺腫 (Silent subtype 3 adenoma) であった。術後GH、IGF-I は正常で推移している。衝動性尺度である BIS スケールは術前 120 点から術後 98 点へ改善し、自己評価式スコアも改善を認めた。セルトラリンは中止し、 衝動的な食行動が減り、術後11 か月経過した時点で体重は88.0kg まで減少し ている。

【考察】先端巨大症は健常群と比較して衝動性は低いとされ、腹内側前頭前 野の灰白質体積の拡大が衝動性の低さと関与すると考えられている。また、 PRL 産生下垂体腺腫においても健常群と比較して衝動性が低いことが報告さ れている。しかしながら本例に抒いては衝動性が高く過食を認め、それらが 術後改善し体重が減少した。この機序は明らかではないが、灰白質体積など の器質的な変化が短期間で起こるとは考えにくく、またGH、IGF-I、PRLの 低下が衝動性の改善に直接寄与したという報告はない。このことから、治療 薬であるアトモキセチン効果の修飾を介した機序などが、間接的に衝動性の 改善に影響した可能性が考えられる。 


\section{先端巨大症の早期発見 一現状と課題一}

○木下 康之 ${ }^{1)}$ ，富永 篤 $^{2)}$, 碓井 智 ${ }^{1)}$, 有田 和徳 ${ }^{3)}$, 迫口 哲彦 ${ }^{2)}$, 栗栖 薰 ${ }^{1)}$

${ }^{1)}$ 広島大学大学院医歯薬保健学研究院 脳神経外科学, ${ }^{2}$ 県立広島病院 脳神経外科,

${ }^{3}$ ) 鹿児島大学大学院医歯学総合研究科 脳神経外科

【背景と目的】先端巨大症は多彩な疾患を合併し、一人の患者さんに多くの医 師が関わるが、疾患の早期発見に至っているとは言い難い。我々は先端巨大 症の早期発見に有効な方法を検討した。

【対象と方法】 2000 年 1 月-2015年 12 月の期間に初回手術を行った先端巨大症 132 例を対象とした。診断の契機となった症状、診断した医師、合併疾患の治 療歴を検討した。

\section{【結果】}

1) 診断の契機となった症状は顔貌変化・手足の肥大 71 例 (53.8\%)、頭痛 15 例 (11.4\%)，視機能障害 10例 (7.6\%)、睡眠時無呼吸症候群 7例 (5.3\%) が多かった。 2) 診断した医師は内科医 57 例 (43.2\%)、脳神経外科医 45例 (34.1\%) が多かった。

3) 合併疾患には高血圧 (47例)、糖尿病 $(41$ 例)、大腸ポリープ・大腸癌 $(16$ 例)、睡眠時無呼吸症候群 (12例)、手根管症候群 (11例) などを認めたが、治 療担当医師が先端巨大症と診断できた症例はそれぞれ $5 / 47$ 例 (10.6\%)、13/41 例 (31.7\%)、2/16例 (12.5\%)、7/12例 (58.3\%)、1/11例 (9.1\%)であった。

4)かかりつけ医が臨床症状から先端巨大症を疑い診断できたのは47例 (35.6\%) であった。仮に本研究の対象患者において、糖尿病有病者に先端巨大症スク リーニング検査を行い、全例診断に至ったとすると、かかりつけ医の診断率 は66例 (50.0\%) に上昇することが分かった。

【結語】先端巨大症患者は様々な合併疾患の治療を受けていながら、先端巨大 症と診断されないままのことも多い。先端巨大症の早期発見には、先端巨大 症特有の合併疾患を有する患者にスクリーニング検査を行うことが1つの方法 である考えられた。 

の一例

$\bigcirc$ 秋山 優, 近藤 学, 幡中 雅行, 竹田 孔明, 谷澤 幸生 山口大学医学部附属病院 第三内科

症例は41歳、女性。20XX年1月に健診ではじめて高血圧を指摘され、近医 にて治療開始となる。同年 3 月、自宅で倒れているのを家人が発見し当院へ 救急搬送された。搬送時、JCS20の意識障害あり、血圧 $174 / 60 \mathrm{mmHg}$ と高值、 左片麻痺あり、CTにて右被殼脳出血を認めたため血腫除去術が施行された。 若年発症の高血圧性脳出血であり二次性高血圧のスクリーニング検査が施行 され、ホルモン基礎值にて $\mathrm{ACTH} 49.7 \mathrm{pg} / \mathrm{ml}$ 、コルチゾール $27.0 \mu \mathrm{g} / \mathrm{dl}$ と軽度 上昇していたため当科紹介となった。軽度の満月様顔貌を認め、畜尿遊離コ ルチゾールは $162.8 \mu \mathrm{g} / \mathrm{day}$ と上昇していた。0.5mgDEX抑制試験では、翌朝 の血中コルチゾールは $21.3 \mu \mathrm{g} / \mathrm{dl}$ と高值であり、また、コルチゾール血中日内 変動は消失していた。 $8 \mathrm{mgDEX}$ 抑制試験では、コルチゾールは前值の $1 / 2$ 以 下に抑制され、CRH試験における ACTH頂值は前值の 1.5 倍以上に増加した。 しかしながら下垂体 MRIでは腫瘍を認めなかったため、確定診断目的に海綿 静脈洞サンプリングを施行したところ、CRH負荷後の右中枢側/未梢側 $(\mathrm{C} / \mathrm{P})$ 比は20.8 (左 $\mathrm{C} / \mathrm{P}$ 比 1.1) と著明に上昇しており下垂体右側に局在する腫瘍の存 在が疑われた。クッシング病の可能性が高いと考え、脳出血後のリハビリを 行いADLが改善された後に治療を行うこととした。本症例は、クッシング徵 候が軽微であったため、脳出血を発症するまでクッシング病の存在が疑われ なかったと推測された。若年の高血圧患者に遭遇した場合、原発性アルドス テロン症をはじめとした様々な二次性高血圧の可能性を検討する必要がある が、クッシング病による二次性高血圧の可能性も考慮すべきである。 


\section{Cushing 病診断における海綿静脈洞サンプリングの有用性}

○迫口 哲彦, 富永 篤, 竹下 真一郎, 岐浦 禎展, 籬 拓郎, 近藤 浩, 川住 知弘

県立広島病院 脳神経外科・脳血管内治療科

【はじめに】ACTH 産生下垂体腺腫 (Cushing病) は非常に小さい腺腫でも症候 性となり、近年の High resolutionの MRIにおいてもしばしば画像上の局在同 定に難渋することがある。我々は以前よりCushing病の診断に際しては、可 能な限り海綿静脈洞サンプリング (以下CSS)を行っている。最近の症例から CSS施行例と非施行例を提示してその有用性について報告する。

【症例】2015年 4 月以降にCushing 病疑いで紹介となり CSS を行った 3 例と CSS を行わなかった 1 例。全例で日内変動の消失、CRH・DDAVPに対する反応な どの異常所見を認めた。CSSは両側海綿静脈洞の後半部で採血を行い、CRH 刺激とプロラクチン值での補正も参考に評価を行い、中枢・末梢比 $>3$ をもっ て下垂体性の診断とした。2例ではMRI所見と一致する下垂体腫瘍の局在を 強く疑う所見を認め、いずれも手術で寛解を得た。下垂体性を示唆する所見 が得られなかった1例は、MRIで腫瘍が明らかでなかったこと、デキサメサ ゾン抑制試験でCushing 病パターンでなかったこと、ACTH、コルチゾール もさほど高值でなかったことなどから経過観察とした。

急速な症状の進行があり腫瘍の局在が明膫であった1例において、CSSを施行 せず手術を施行、明らかな腺腫を認め手術で全摘したもののホルモン低下が 得られず、実は別の微小腺腫が存在していたdouble adenomaの症例があった。 【結論】Cushing病の診断において、CSSは有用である。各種内分泌検査や画像 検査と組み合わせることで、より診断の精度や治癒率を高めることが可能と なると思われる。 


\section{プロラクチン分泌能の低いプロラクチノーマが疑われる1例}

○野津 雅和, 三宅 仁美, 守田 美和, 金沢 一平, 山本 昌弘,

山内 美香, 杉本 利嗣

島根大学医学部 内科学講座内科学第一

【症例】 26 歳女性。主訴は無月経。X -8 年に第 1 子出産後より乳汁漏出あり。 $\mathrm{X}-2$ 年に近医で高プロラクチン $(\mathrm{PRL})$ 血症 $47 \mathrm{ng} / \mathrm{mL}$ を初めて指摘され、一 時的にカベルゴリン内服し PRL $10 \mathrm{ng} / \mathrm{mL}$ 低下した。 $\mathrm{X}-1$ 年からうつ病に 対しSNRIが開始となった。X年7月以降無月経となり PRL $131 \mathrm{ng} / \mathrm{mL}$ であっ たためSNRIを中止、クロチアゼパムに変更したがPRL $165 \mathrm{ng} / \mathrm{mL}$ と高值が持 続し、頭部MRIにて下垂体腫瘍を認めたため当科初診。初診時不眠に対しト ラゾドン内服あり。頭痛や視野障害なし。胸壁疾患なし。164cm、50kg。PRL 87.3ng/mL、FT4 1.0ng/dL、TSH $2.52 \mu \mathrm{U} / \mathrm{mL} 、 \mathrm{LH} 5.0 \mathrm{IU} / \mathrm{mL} 、$ FSH $10.2 \mathrm{IU} /$ $\mathrm{mL} 、 \mathrm{E} 229 \mathrm{pg} / \mathrm{mL}$ 。下垂体機能検査にて LH、FSHは低反応、他は正常反応。 $\mathrm{TRH}$ 負荷にて PRL 前值 $87.3 \rightarrow$ 頂值 15 分後 $149 \mathrm{ng} / \mathrm{mL}$ 、GHRP-2負荷でのPRL 反応率は $141 \%$ 。下垂体造影MRIで下垂体左側に遅延性の造影効果を有する $7 \mathrm{~mm}$ 大の腫瘤あり、その上部に囊胞変性を示唆する $\mathrm{T} 2$ 高信号領域あり。下 垂体茎の偏移なし。T1で後葉高信号あり。トラゾドン中止するも PRLは改善 なく、カベルゴリンを開始した。 $1 \mathrm{mg} /$ 週まで増量後PRL $3.9 \mathrm{ng} / \mathrm{mL}$ 一低下し 月経は回復したが、X +2 年時点で下垂体腫瘍はわずかに増大傾向である。

【考察】PRL軽度上昇例の原因は多彩であり鑑別に悩む例も存在する。本例は 被疑薬中止後も PRLの低下はなく、下垂体茎所見から視床下部性も考えにく い。プロラクチノーマは高分化の腫瘍細胞が多く、ミクロアデノーマであっ ても PRL 100-250ng/mLを呈することが多い。しかし組織学的に多ホルモン 産生性の腫瘍において腫瘍体積に比しPRL值が低いことなども報告されてお り、本例においてもPRL分泌能が低いプロラクチノーマの可能性が考えられ た。 


\section{進行性の低Na 血症を契機に産裖早期に診断し得たSheehan 症候群の1例}

$\bigcirc$ 白蓋 雄一郎 ${ }^{1)}$, 浅田 裕美 ${ }^{1)}$, 三原 由実子 ${ }^{1)}$, 品川 征大 ${ }^{1)}$,

岡田 真紀 ${ }^{1)}$, 李 理華 $^{1)}$, 澁谷 文恵 ${ }^{1)}$, 田村 功 $^{1)}$, 前川 亮 $^{1)}$, 竹谷 俊明 ${ }^{1)}$, 田村 博史 $^{1)}$, 竹田 孔明 ${ }^{2)}$, 谷澤 幸生 $^{2)}$, 杉野 法広 ${ }^{1)}$

${ }^{1)}$ 山口大学医学部附属病院 産科婦人科, ${ }^{2)}$ 山口大学医学部附属病院 第三内科

Sheehan症候群は、分娩時大量出血により沉下垂体機能低下を来す疾患で、 分娩後早期の発症は稀とされている。今回、進行性の低 Na血症を契機に診断 し得たSheehan 症候群の1例を経験した。症例は、31歳の初産婦で、近医に て妊娠 40 週 1 日に経臸分娩となったが、弛緩出血を認めたため当科へ搬送と なった。出血性ショックおよびDICの状態で、止血困難な子宮内からの持続 的な出血を認めたため、同日、緊急子宮全摘術を施行した。術後ICU入室 1 時間後に再度ショックバイタルとなり腹腔内出血が疑われたため再開腹によ る止血術を施行した。総出血量 $7900 \mathrm{~g}$ で、輸血はRBC28単位、FFP32 単位、 PC60単位であった。進行性の低 $\mathrm{Na}$ 血症を認めたため術後 4 日目に基礎ホルモ ン值（ACTH、TSH、PRL、FSH、LH、FT3、FT4、cortisol）を測定したとこ ろいずれも低值で、ステロイドおよび高張食塩水投与により低 $\mathrm{Na}$ 血症は改善 した。各種負荷試験 (CRH、TRH、LH-RH、インスリン低血糖、GHRP-2) で はいずれも低反応で、術後9日目のMRIでは下垂体辺縁のみが造影され内部 の造影効果を認めないhook-shaped enhancementを呈していたため、Sheehan 症候群と診断し、ホルモン補充療法を開始した。大量出血例の産裖管理には Sheehann症候群を念頭に置いて管理する必要があると思われる。 


\section{難産での出産後に発症した下垂体機能低下症の1例}

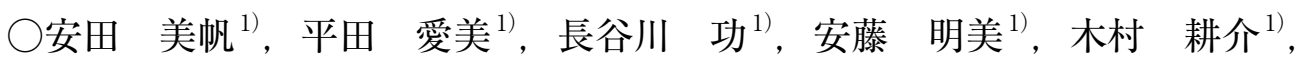

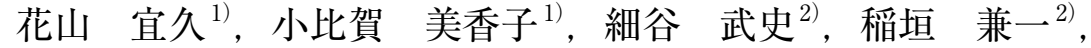

大塚 文男 ${ }^{1)}$

${ }^{1)}$ 岡山大学病院 総合内科, ${ }^{2)}$ 岡山大学病院 内分泌センター

【症例】40代·女性

【主訴】腰痛・下肢関節痛・食欲低下・体重減少

【現病歴】201X-2年 12 月に第 1 子を 24 時間の難産の末に出産。産後驰緩出血 を伴うも輸血は要さず同日に止血した。産後乳汁分泌を認めず無月経が持続、 産後 3 ケ月より易疲労感・腰痛・下肢関節痛・食欲低下・体重減少を認め、諸 症状の精査目的に入院。入院時、全身倦总感が著明であり、るいそう・低血 圧・皮膚乾燥・脱毛・乳房萎縮を認めた。血液検查では低血糖・低 Na 血症 と肝機能障害を認め (FPG 69mg/dl, Na 125mmol/l, T-Bil 0.73mg/dl, AST 371U/1, ALT 290U/1)、内分泌検査ではACTH・TSH・PRL・GH $(\mathrm{ACTH}<$ $1.0 \mathrm{pg} / \mathrm{ml}$, cortisol $0.2 \mu \mathrm{g} / \mathrm{dl}$, TSH $7.04 \mu \mathrm{U} / \mathrm{ml}$, FT4 0.43ng/dl, PRL <1.0ng/ $\mathrm{ml}$, IGF-I $25 \mathrm{ng} / \mathrm{ml}$ ) を含む沉下垂体機能低下を認めたが後葉機能は保たれて いた。下垂体 4 者刺激試験で、ACTH $\cdot$ cortisol $\cdot \mathrm{PRL}$ は無反応、TSH $\cdot \mathrm{LH} \cdot$ FSH は遅延反応を呈した。GHRP-2刺激では GH 頂値 $<9 \mathrm{ng} / \mathrm{ml}$ と重症 $\mathrm{GH}$ 分 泌不全を認めた。頭部MRIでは下垂体はempty sella所見を呈したが、抗下 垂体抗体・ACE - lysozyme ・ IgG4に異常值を認めなかった。腹部超音波で は脂肪肝を呈していた。Sheehan 症候群による汎下垂体機能低下症と診断し、 hydrocortisone - levothyroxin · somatropin順次補充した。ホルモンの充足に 伴い体重減少・腰痛・下肢関節痛・食思不振・肝機能異常は速やかに軽快した。 【考察】本例では出産から発症まで約 3 ヶ月と短期であり出産前の視床下部・ 下垂体疾患の潜在も否定できないが、産裖期の下垂体においては著しい出血 歴がなくとも難産により下垂体虚血に陥る可能性があり、興味深い症例とし て文献的考察も含埇告する。 


\section{中枢性尿崩症と骨髄異形成症候群を合併した1例}

○末廣 泰子 ${ }^{1,2}$, 廣重 俊典 ${ }^{1,2)}$, 富永 貴元 ${ }^{1,2)}$, 高橋 徹 ${ }^{2)}$, 井上 康 $^{1)}$

${ }^{11}$ 山口県立総合医療センタ一 内分泌内科， $\left.{ }^{2}\right)$ 山口県立総合医療センタ一 血液内科

【緒言】骨髄異形成症候群の稀な合併症として、中枢性尿崩症が報告されてい る。

【症例】51歳男性。15年前と8年前に精巣腫瘍に対して手術・化学療法・放射 線療法を施行され、現在は完治している。口渴感と多飲を主訴に当科を受診。 1 日 5,000ml 以上の低浸透圧性多尿を認めた。下垂体 MRIではT1強調像にお いて後葉の高信号が消失しており、中枢性尿崩症を疑い負荷試験を行った。 高張食塩水負荷試験では、尿量の減少は認めず、血漿浸透圧が上昇しても $\mathrm{ADH}$ は低值で推移し無反応であった。デスモプレシン負荷試験では、尿量の 減少と尿浸透圧の上昇を認めた。以上の結果から中枢性尿崩症と診断し、デ スモプレシン内服を開始したところ、多飲・多尿は改善傾向となった。

また、当科初診時の血液検査で白血球減少と貧血があり、数\%の芽球様異常 細胞を認めた。骨髄穿刺を行ったところ、血球 3 系統の異形成と芽球比率の増 加がみられ、複雑染色体異常 (46, XY, +1, der (1；7) (q10；p10), del (20) (q1?)）を伴うこと、化学療法・放射線療法の治療歴があることから、治療関 連骨髄異形成症候群（芽球増加を伴う不応性貧血-2)の診断となった。なお髄 液検査と頭部造影MRIを行ったが、悪性腫瘍の中枢神経浸潤を示唆する所見 は認めなかった。

【考察】中枢性尿崩症を合併した急性骨髄性白血病や骨髄異形成症候群では、7 番染色体異常を高頻度に認めることが報告されている。本例も7番染色体異常 を伴っており、尿崩症との関連が推測された。 


\section{糖尿病増悪と多尿を契機に診断に至つたIgG4関連下垂体炎 の1例}

○庄司 恭子 ${ }^{1)}$, 松澤 和彦 $^{2)}$, 小椋 貴文 $^{3)}$, 村脇 あゆみ ${ }^{4)}$,

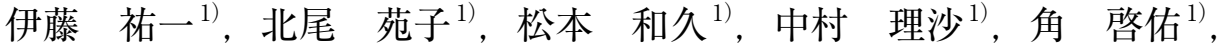

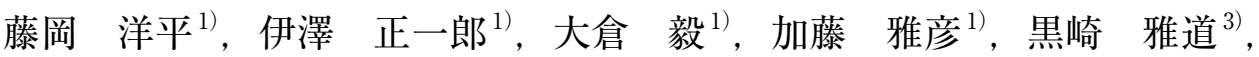

谷口 晋一 ${ }^{2}$, 山本 一博 ${ }^{1)}$

1) 鳥取大学医学部 病態情報内科, ${ }^{2)}$ 鳥取大学医学部 地域医療学講座,

3) 鳥取大学医学部 脳神経外科, ${ }^{4)}$ 鳥取県立厚生病院 内科

【症例】57歳男性。前医にて 2 型糖尿病を内服加療中であり、長年 HbAlc $6 \%$ 台で経過していた。X年 6 月は HbAlc 6.5\%、空腹時血糖 $103 \mathrm{mg} / \mathrm{dL}$ であった。 $\mathrm{X}$ 年 8 月に HbAlc 7.3\%、随時血糖 $168 \mathrm{mg} / \mathrm{dL}$ と糖尿病増悪を認めた。同時期 に清涼飲料水の多飲、尿量増加を伴っていたため、清涼飲料水による糖尿病 増悪に由来した多尿の可能性が考えられた。しかし清涼飲料水中止後のX年 10 月に $\mathrm{HbAlc} 7.5 \%$ とさらに糖尿病増悪があり、多尿、口渇多飲も増悪傾向で あった。尿崩症が疑われ、当科紹介となった。尿量 $3000 \mathrm{~mL} /$ 日以上、尿浸透 圧 (Uosm) 130mOsm/kg、単純MRI T1 強調画像で下垂体後葉の高信号消失、 $5 \%$ 高張食塩水負荷にて血清 $\mathrm{Na} 150 \mathrm{mEq} / \mathrm{L}$ 時のバゾプレシン $1.5 \mathrm{pg} / \mathrm{mL、バゾ}$ プレシン負荷試験にてUosm $541 \mathrm{mOsm} / \mathrm{kg}$ を認め、中枢性尿崩症と確定診断 した。抗核抗体陰性、IgG4 $24.4 \mathrm{mg} / \mathrm{dL}$ であった。原因精査目的の造影 MRIで は下垂体茎から後葉のびまん性の腫大および造影効果を認めた。下垂体生検 を施行したところ、IgG4関連下垂体炎の診断に至った。造影CT では IgG4 関 連自己免疫性膵炎を疑う所見は指摘できなかった。

【考察】gG4関連疾患患者では明らかな自己免疫性膵炎でなくても膵内分泌機 能障害が高頻度に認められるとの報告もあり、本症例では糖尿病増悪に $\operatorname{IgG}$ 関連疾患が関与した可能性が考えられた。血糖コントロール増悪と多尿を来 した場合、糖尿病の発症または増悪による一連の病態のみでなく、IgG4 関連 下垂体炎の発症も考慮する必要がある。 


\section{数年の経過でインスリン依存状態となった ZnT8抗体陽性 1 型糖尿病の 1 例}

○児玉 尭也 ${ }^{1)}$, 奥崎 健 $^{1)}$, 由田 彩佳 $^{1)}$, 磯山 正子 $^{1)}$, 大崎 慶子 ${ }^{1)}$,

川崎 広平 $^{1)}$, 米田 真康 $^{2)}$

${ }^{1)}$ 三原市医師会病院, ${ }^{2)}$ 広島大学大学院分子内科学 内分泌 ·糖尿病内科

症例は 27 歳女性。2012年 3 月初旬より口渇、多飲多尿があり、同年 4 月に 健康診断で血糖高值を指摘され、近医総合病院を受診した。糖尿病性ケトー シスの診断で入院しインスリン強化療法が開始された。抗GAD抗体、抗イン スリン抗体、抗IA-2抗体は全て陰性で、内因性インスリン分泌能も保たれて おり、2型糖尿病と診断された。入院中にインスリン治療を離脱し、経口血糖 降下薬の内服で退院した。その後度々通院を自己中断し、血糖コントロール 増悪のため入退院を繰り返した。2015年1月7日に糖尿病性ケトアシドーシ スを発症し、近医総合病院に入院した。インスリン離脱に至らず、混合型イ ンスリン製剤の皮下注射と経口血糖降下薬の内服で退院したが、HbAlc 8\% から 10\%と高值で経過した。当院内科を紹介受診し、2015年12月 3 日より糖 尿病教育入院を行い、インスリン強化療法で血糖コントロール良好となり同 年 12 月 16 日に退院した。入院時の検査で、空腹時血中 CPR $0.77 \mathrm{ng} / \mathrm{ml}$ 、蓄尿 CPR $18.3 \mu \mathrm{g} /$ 日と内因性インスリン分泌能は低下していた。抗GAD抗体、抗 IA-2 抗体は陰性で、抗インスリン抗体 $50 \mathrm{U} / \mathrm{ml} 、 \mathrm{ZnT}$ 抗体 $153.0 \mathrm{IU} / \mathrm{ml}$ だった。 HLA 遺伝子型はDRBI * 09:01-DQBI* $03: 03$ であり日本人 1 型糖尿病疾患 感受性に関連するハプロタイプを有していた。本症例は、発症時には抗 GAD 抗体、抗インスリン抗体、抗IA-2抗体の3種の膵関連自己抗体が陰性であっ たが、数年の経過でインスリン依存状態となり、ZnT8抗体陽性が判明し、1 型糖尿病と診断し得た。現在 ZnT8抗体は保険収載されていないが、単独陽性 の 1 型糖尿病の症例が存在するため、他の自己抗体が陰性であっても 1 型糖尿 病が疑わしいとき、ZnT8抗体の測定は意義深いと思われる。 
SGLT2阻害薬の安全かつ効果的な使用方法の検討

○岩田 康義, 次田 誠

独立行政法人 労働者健康福祉機構 香川労災病院 内科

【目的】SGLT2 阻害薬は確実な血糖降下、体重減少効果などが期待されている が、死亡症例も含め脳梗塞や腎機能低下、皮疹など様々な副作用も報告され ている。それら副作用への対策効果を検証し、SGLT2 阻害薬は空腹時血糖值 の改善作用が大きいことがCGMなどで報告されており、その効果をより高め る食事療法についても検討を行った。

【対象と方法】HbA1c $8 \%$ 以上のコントロール不良の 2 型糖尿病患者 27 例に SGLT2 阻害薬を追加し、飲水指導、血圧や体重、尿量測定などの生活調査指 導を行い、食事時間、食事内容、服用時間、血糖值、尿糖排泄量、体液量な どの変化を検討した。

【結果】 3 ケ月後 HbAlcは $8.6 \pm 1.2$ から $7.7 \pm 0.9 \%$ に低下した。夜間に $69 \mathrm{mg} / \mathrm{dl}$ 以下の低血糖は認めず空腹時血糖值を有意に低下させた。22時以降に夕食を 摂取していた患者さんに 20 時までに夕食を済ませた 8 人では特に空腹時血糖 值、体重が有意に低下した。しかし 27 例中 7 例では依然として食後の高血糖 を認め日内変動幅の大きい血糖状態であった。また季節性に関係なく5例で eGFRの低下、7例でFENaの低下、6例で尿中浸透圧の増加、1例で尿路感染 症の悪化を認めた。

【考察】SGLT2 阻害薬は、主に空腹時血糖值を低下させる薬剤と思われ、食後 の血糖值を抑えるグリニド薬や $a$ GI 薬などの併用が効果的と推察する。また 日中に多くの尿糖排泄を認め、夕食時間を早め夕食の糖質を減量することで より夜間の高血糖を低下させると思われる。また具体的な飲水摂取量の指示 や体重変動チェックなどを指導しないと体液量の変化に対し、十分な効果が 得られないと思われる。 
SACIテストにおける擬陽性を排除し腫瘍局在を診断し得た インスリノーマの1例

○梶川 隆治郎, 江草 玄太郎, 久保田 益亘, 大久保 博史, 大野 晴也, 沖 健司, 米田 真康

広島大学病院 内分泌 ·糖尿病内科

【症例】60歳代男性

【現病歷】20X 年4月、繰り返す意識消失を主訴に近医総合病院を受診し、精查 目的で同院に入院した。意識消失時の血液検查で低血糖を指摘され、同年 5 月 に当院に転院した。

【経過】早朝空腹時血糖值 $36 \mathrm{mg} / \mathrm{dl}$ 、血中 IRI $8.0 \mu \mathrm{U} / \mathrm{ml} 、 \mathrm{CPR} 2.3 \mathrm{ng} / \mathrm{ml}$ より Serviceの基準を満たし、インスリノーマを疑った。造影CT検査で膵頭部に 早期濃染を示す $15 \mathrm{~mm}$ 大の腫瘍を認めた。腫瘍の局在診断のため、選択的動 脈内カルシウム注入試験 (selective arterial calcium injection test、SACI 試験) をカルチコール $0.025 \mathrm{mEq} / \mathrm{kg}$ (Doppman 原法) で施行したが、腫瘍の栄養動 脈以外の血管に拀いてもインスリン值が前值の 2 倍以上となり膵頭部以外の微 小腫瘍の存在を否定しえなかった。原因として、動脈内に注入したカルシウ ムが体循環 1 周後に、腫瘍からのインスリン分泌を促進させた可能性を考えた。 そこで、SACI 試験を再検時に、カルチコール静注30秒後の上腸間膜動脈内カ ルシウム濃度を測定したところ、注射前 $1.17 \mathrm{mmol} / \mathrm{L}$ から注射後 $1.50 \mathrm{mmol} / \mathrm{L}$ と上昇が認められた。その後カルチコール濃度を減量 $(0.0045 \mathrm{mEq} / \mathrm{kg})$ すると、 腫瘍の栄養動脈のみでインスリン值の上昇を認め、膵頭部以外の微小腫瘍の 存在は否定的であると考えた。外科へ転科し、膵頭部の腫瘍核出術を施行さ れ以降、低血糖は消失した。

【考察】本症例はDoppman 原法から算出したカルチコール投与量ではカルシウ ム濃度が過剩であり、栄養動脈以外でもインスリン濃度の上昇を来した可能 性がある。SACIテストで為陽性を疑う場合に、循環血液中のカルシウム濃度 の上昇を来す可能性を考え、注入カルチコールの濃度を調整する必要がある ことが示唆された。 


\section{当院で経験した甲状腺䯣様癌の超音波所見の検討}

【コメディカル演題】

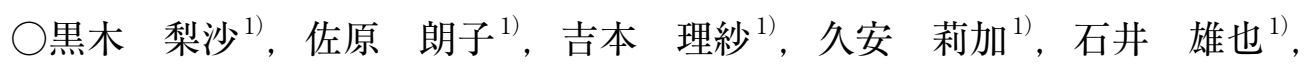

山内 陽平 $^{1)}$, 高井 沙織 $^{1)}$, 寺尾 陽子 ${ }^{1)}$, 友國 淳子 ${ }^{1)}$,

筑地 日出文 ${ }^{1)}$, 横田 敏彦 ${ }^{2)}$

1) 公益財団法人 大原記念倉敷中央医療機構 倉敷中央病院 臨床検査技術部,

2) 公益財団法人 大原記念倉敷中央医療機構 倉敷中央病院 内分泌代謝・リウマチ内科

【はじめに】甲状腺髄様癌 (medullary thyroid carcinoma、以下 MTC) は甲状 腺傍濾胞上皮細胞由来の腫瘍で、甲状腺癌の 1 ～ $3 \%$ と比較的稀な癌である。 また、その超音波像は多様であり、MTCに特異的な所見はないとされている。 今回我々は、当院で経験した $\mathrm{MTC}$ 症例の超音波所見について報告する。

【対象】 2007 年 7 月から 2015 年 12 月までの 8 年間に病理診断にて MTC と診断 された 7 症例、複数病変を含む 10 病変を対象とし、それぞれの超音波画像を 甲状腺結節 (腫瘤) 超音波診断基準にもとづき分類した。年齢は34-61歳 (平均 47 歳)、男性 2 例、女性 5例、腫瘍径は 5-35mm (中央值 $18 \mathrm{~mm}$ ) であった。

【超音波所見】腫瘤の形状は類円形〜楕円形の形状整なものが5例、分葉形や 切れ込み状の形状不整なものが5例であった。腫瘤の境界は明瞭平滑なものが 5 例、明瞭粗雑なものが 3 例、不明瞭なものが 2 例であった。境界部低エコー 带を有するものは認めなかった。内部の性状は低エコーが6例、低エコーと等 エコーの混在するものが 4 例、均一性は、均一なものが 2 例、不均一なものが 8例であった。腫瘤内に石灰化を示す高エコーを有するものが6例に認められ た。後方エコーの消失のない高エコー輝点だけの微小な石灰化をわずかに認 めるものが3例であった。MTCに特徵的な所見とされる後方エコーが消失す る粗大な、いわゆる牡丹雪状の石灰化を有するものが3例であった。

【考察】MTCの超音波像は多彩であり特異的な所見はないとされているが、今 回我々が経験したMTC症例も同様であり超音波所見での髄様癌の診断は困難 であった。しかし、多くの症例が悪性を疑う所見を有しているため、細胞診 や腫瘍マーカー測定などにより確定診断へと進むことは可能である。 


\section{甲状腺濾胞性腫瘍の超音波診断：Real-time Tissue Elastographyを用いた検討 【コメディカル演題】}

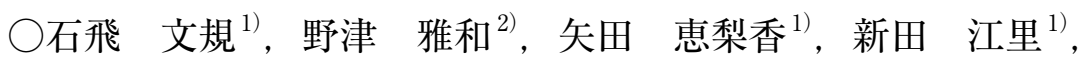

三島 清司 ${ }^{1)}$, 山内 美香 ${ }^{2}$, 杉本 利嗣 ${ }^{2)}$, 石川 典由 ${ }^{3)}$, 長井 篤 ${ }^{1)}$

${ }^{1)}$ 島根大学医学部附属病院 検査部, ${ }^{2}$ 島根大学医学部 内科学講座内科学第一,

${ }^{3)}$ 島根大学医学部附属病院 病理部

【はじめに】甲状腺濾胞性腫瘍の良悪性の診断は穿刺細胞診では困難であり、 超音波診断能の向上が期待されているが、Bモード法やカラードプラ法のみで は診断困難な例が多い。近年のメタアナリシスで、全組織型を含む甲状腺癌 の鑑別に、Real-time Tissue Elastography (以下、RTE) が有用と報告された。 しかしこれまでの検討に含まれる濾胞性腫瘍例はわずかで、濾胞性腫瘍の鑑 別にRTEが有用かは明らかではない。今回、濾胞性腫瘍の良悪性鑑別におけ るRTEの有用性について検討した。

【対象】2009年 4 月から 2016年3月の間に甲状腺摘出術によって病理診断が確 定した濾胞性腫瘍 54 例 (腺腫 42 例、濾胞癌 12 例)。

【方法】RTE所見と病理組織診断を比較した。RTEは、硬度の定性表示を視覚 的に半定量化し4段階に分類した（Grade1-4：硬度が高い方を4）。さらに濾胞 癌の特徵の 1 つされる、腫瘍内部が緑色、辺縁が青色に表示されるパターン (以下、辺縁青色パターン) の有無を判別した。

【結果】濾胞癌は全例微小浸潤型であった。RTE所見は、濾胞癌でGrade 1/2/3/4 が各々 $1 / 7 / 4 / 0$ 例、腺腫で 7/28/6/1例と多様であった。Grade 3 また は4を呈した11例中、腺腫が7例 (64\%)であった。辺縁青色パターンは滤胞癌 で4例 (33\%)、腺腫で10例 (24\%) と2 群間で差を認めなかった。

【考察】滤胞性腫瘍は小濾胞構造の集塊からなり、濾胞腔内にコロイドを殆ど 認めず細胞密度が高いことが、腺腫においてもGradeが高い原因の1つと考え た。微小浸潤型の濾胞癌は、腫瘍被膜も保たれ腺腫との組織学的な差異が少 ないため、今回はGradeが低い濾胞癌例が多かったと推察される。

【結語】RTEによる滤胞性腫瘍の良悪性鑑別は困難であることが示唆された。 


\section{当院での原発性副甲状腺機能六進症 40 例における超音波検 査の副甲状腺検出率の検討 【コメディカル演題】}

○吉本 理紗 ${ }^{1)}$, 佐原 朗子 ${ }^{1)}$, 久安 莉加 ${ }^{1)}$, 石井 雄也 $^{11}$, 黑木 梨沙 ${ }^{1)}$,

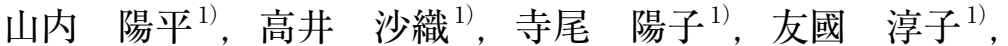

筑地 日出文 ${ }^{1)}$, 横田 敏彦 ${ }^{2)}$

1) 公益財団法人 大原記念倉敷中央医療機構 倉敷中央病院 臨床検查技術部

2) 公益財団法人 大原記念倉敷中央医療機構 倉敷中央病院 内分泌代謝・リウマチ内科

【目的】原発性副甲状腺機能充進症（以下 $\mathrm{pHPT}$ )の治療では、病的副甲状腺 を外科的に摘出することが第一選択となっており、術前に正確な局在診断を 行うことが大変重要である。pHPTの局在診断法は超音波検査 (以下 US) · $\mathrm{MRI} \cdot 99 \mathrm{mTC}-\mathrm{MIBI}$ シンチグラフィー (以下 MIBI) ・CTが知られており、今 回我々は病的副甲状腺のUSの検出率とUSでの未検出腺、他画像との不一致 腺について他画像・術中所見・病理診断からその原因を検討した。

【対象】2013年6月から 2016年5月までに当院で副甲状腺摘出術を施行し、病 理診断の確定したpHPT 患者40例 43 腺を対象とした。性別は男性 11 例、女性 29 例、平均年齢は 62.0 歳 (27～84歳)であった。

【結果】検出率は、USが 88.4\% (38/43腺)，MRIが 100\% (41/41腺)，MIBIが 97.6\% (41/42腺)，CT が $97.4 \%$ (38/39腺)であった。病的副甲状腺をUSで検 出できなかったものは4腺、他画像との不一致腺が1腺あり、病理診断から他 画像で指摘のものが腺腫であった。 MIBI ・ CT でも検出できなかったものが 1 腺、前縦隔に存在するものが1腺、USのみが指摘できていなかったものが不 一致腺を含め 3 腺であった。術中所見や病理診断から検討すると、MIBI $\cdot \mathrm{CT}$ でも検出できなかったものは手術の際に甲状腺左下に薄く張り付くように観 察され、USでは検出困難な大きさ・形状であったと考元られる。また、縦隔 内はUSでの観察は困難な場合が多い。一方、USのみが指摘できなかった 2 例 は甲状腺周囲から約 $10 \mathrm{~mm}$ 大の副甲状腺が摘出されており、そのどちらも注 意深く描出を行えばUSでも検出可能であった。

【結語】USは術者の技量に左右されるといわれており、USを施行する際は常 に甲状腺周囲の病変検索も意識し注意深く観察することが重要である。 


\section{甲状腺穿刺吸引細胞診「鑑別困難」症例の再評価}

\section{【コメディカル演題】}

○遠藤 由香利 ${ }^{1)}$, 大野 千恵子 ${ }^{1)}$, 松重 貴大 $^{1)}$, 持田 洋利 ${ }^{1)}$,

山田 恭子 ${ }^{1)}$ ，伊澤 正一郎 $^{2)}$ ，松澤 和彦 ${ }^{2)}$, 福原 隆宏 ${ }^{3)}$,

覚道 健一 ${ }^{4)}$, 梅北 善久 ${ }^{1)}$

1) 鳥取大学医学部附属病院病理部, 2) 鳥取大学医学部病態情報内科学分野,

${ }^{3)}$ 鳥取大学医学部 感覚運動医学講座耳鼻咽喉 · 頭頸部外科学分野,

4) 近畿大学医学部奈良病院 臨床検査部

【はじめに】甲状腺癌取り扱い規約 7 版が改訂し，「鑑別困難」のカテゴリーは 「意義不明」と「滤胞性腫瘍」に二分された。両区分とも検体適正症例の $10 \%$ 以 下が望ましいが，一般病院での検討報告はこれまで殆どない. 今回「鑑別困難 」症例を再評価し，報告時考慮すべき点を検討した。

【対象と方法】2014年1月～2014年12月の間に当院で判定した甲状腺細胞診標 本 (他院標本除く)の「鑑別困難」症例を対象とし, 直接塗抹標本を再鏡検した。 判定は「意義不明」及び「濾胞性腫瘍」に分類後, 各区分の再検率, 術後組織型 を検証した．また，具体的判定理由 (1)乳頭癌を示唆するが少数, (2)腺腫様甲 状腺腫と乳頭癌の鑑別困難, (3)慮胞性腫瘍と乳頭癌の鑑別困難, (4)濾胞性腫 瘍を疑う，（5滤胞性腫瘍を疑うが他の病変を否定不可）を評価した。

【結果】検体は 229 結節 (168患者), 再検査は31結節で施行し, 初回穿刺 198 結 節中の鑑別困難 29 症例 (14.6\%) を対象とした。「意義不明」は 21 件 (適正症例 中 $12.5 \%)$, 「濾胞性腫瘍」は 8 件 (4.8\%) であった。再検査は「意義不明」の 12 件 (57.1\%) で施行 (うち5 件で判定可能), 「濾胞性腫瘍」は再検査 0 件であった. 手術は「意義不明」の 12 件で施行され, 組織型と具体的判定理由の内訳は乳頭 癌 9 件 (1) 7 件, (2) 0 件, (3) 2 件), 滤胞腺腫 1 件 (3) 1 件), 腺腫様甲状腺腫 2 件 (2) 1 件, (3) 1 件) であった。「濾胞性腫瘍」は5 件で濾胞腺腫 4 件 (4) 3 件, (5) 1 件), 腺腫様甲状腺腫 1 件 (5) 1 件) であった.

【まとめ】「意義不明」は基準よりやや高い割合を占めた。「意義不明」は再検査 が望ましいとあるが，今回乳頭癌症例のうち(1)に分類した症例は(2)(3) と比較 し有意に多く, 具体的理由の提示は悪性危険度や再検査の目安に有用である 可能性が示された。 
$\bigcirc$ 原田 美香 ${ }^{1)}$, 香田 浩美 ${ }^{1)}$, 小寺 明美 ${ }^{1)}$ ，山口 大介 ${ }^{1)}$,

内野 かおり ${ }^{2)}$, 能登原 憲司 ${ }^{2)}$

1) 公益財団法人 大原記念倉敷中央医療機構 倉敷中央病院 臨床検査技術部 病理検査室

2) 公益財団法人 大原記念倉敷中央医療機構 倉敷中央病院 病理診断科

【はじめに】充実性成分を有する甲状腺癌はまれに経験されるが、組織分類 は混沌としており、細胞像についても知見は乏しい。取扱い規約では、少し でも充実性成分を含むものを低分化癌とする一方、最近の国際分類 (Turin criteria）は核所見なども加味し、低分化癌の定義をより狭めている。今回我々 は、充実性成分を有する甲状腺癌の細胞像について上記分類と照らし合せて 検討した。

【対象と方法】2009年1月から 2016年4月までに切除された甲状腺癌症例のう ち、組織で充実性成分を有すると記載されていた6例を対象とした。Turin criteriaに準じると、充実性成分を伴う乳頭癌 4 例、低分化癌 2 例であった。 これらの症例のFNAについて集塊形状、出現形態、核所見を解析した。

【結果】集塊形状 : 全例で乳頭状や濾胞状構造を欠き、不定形な重積集塊であっ た。出現形態：充実性成分を伴う乳頭癌は、通常の乳頭癌に比し結合性の緩 い平面的集塊、散在性細胞として出現していた。低分化癌は大小の集塊とし て出現する傾向にあり、散在性細胞は少なかった。核所見：充実性成分を伴 う乳頭癌では融解状クロマチン、核形不整など通常の乳頭癌の像を示し、低 分化癌では核形不整にそしくクロマチンは凝集増量を示していた。核内封入 体は全例に認めたが、前者で多い傾向にあった。

【まとめ】細胞の出現形態に着目すれば、充実成分を伴う甲状腺癌はFNAで指 摘できそうである。さらに、核所見に着目すれば、詳細な分類もある程度は 推測可能である。充実性成分の存在は、切り出しや組織診断、治療に際し参 考となる情報なので、細胞診の段階で可能な限り把握することは重要である。 


\section{共催・協賛企業一覧}

（五十音順 敬称略）

アクテリオンファーマシューティカルズジャパン株式会社大正富山医薬品株式会社

あすか製薬株式会社

大日本住友製薬株式会社

アステラス・アムジェン・バイオファーマ株式会社

武田薬品工業株式会社

アステラス製薬株式会社

田辺三菱製薬株式会社

アストラゼネカ株式会社

中外製薬株式会社

アッヴイ合同会社

株式会社ツムラ

アボットジャパン株式会社

帝人ファーマ株式会社

エーザイ株式会社

鳥居薬品株式会社

MSD 株式会社

日本イーライリリー株式会社

大塚製薬株式会社

一般社団法人日本血液製剂機構

小野薬品工業株式会社

日本新薬株式会社

科研製薬株式会社

日本ベーリンガーインゲルハイム株式会社

キッセイ薬品工業株式会社

ノバルテイスファーマ株式会社

協和発酵キリン株式会社

ノボノルデイスクファーマ株式会社

興和創薬株式会社

バイエル薬品株式会社

サノフイ株式会社

久光製薬株式会社

株式会社三和化学研究所

ファイザー株式会社

ジエンザイム・ジャパン株式会社

富士フイルムRIファーマ株式会社

塩野義製薬株式会社

持田製薬株式会社

株式会社神陵文庫

ヤンセンファーマ株式会社

ゼリア新薬工業株式会社

ロシュ・ダイアグノステイックス株式会社

第一三共株式会社 


\section{第17回日本内分泌学会中国支部学術集会}

\section{プログラム・抄録集}

発行平成 28 年 8 月

編 集 公益財団法人 大原記念倉敷中央医療機構 倉敷中央病院 内分泌代謝・リウマチ内科 干710-8602 岡山県倉敷市美和 1-1-1 TEL：086-422-0210（代表） FAX：086-421-3424

印 刷 株式会社メッド T701-0114 岡山県倉敷市松島 1075-3 TEL : 086-463-5344 FAX : 086-463-5345 